\title{
HIGH-LEVEL WASTE TANK MODIFICATIONS, INSTALLATION OF MOBILIZATION EQUIPMENT/CHECK OUT
}

Topical Report

By

M. A. Schiffhauer

S. C. Thompson

August 31, 1992

Work Performed Under Contract No. DE-AC07-81NE44139

Prepared for

U.S. Department of Energy

Assistant Secretary for Nuclear Energy

Prepared by

West Valley Nuclear Services Co., Inc.

P.O. Box 191

West Valley, New York 14171-0191

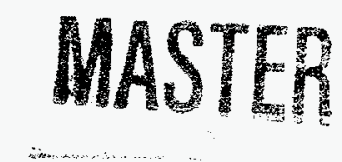

Dor 



\section{DISCLAIMER}

This report was prepared as an account of work sponsored by an agency of the United States Government. Neither the United States Government nor any agency thereof, nor any of their employees, make any warranty, express or implied, or assumes any legal liability or responsibility for the accuracy, completeness, or usefulness of any information, apparatus, product, or process disclosed, or represents that its use would not infringe privately owned rights. Reference herein to any specific commercial product, process, or service by trade name, trademark, manufacturer, or otherwise does not necessarily constitute or imply its endorsement, recommendation, or favoring by the United States Government or any agency thereof. The views and opinions of authors expressed herein do not necessarily state or reflect those of the United States Government or any agency thereof. 


\section{DISCLAIMER}

Portions of this document may be illegible in electronic image products. Images are produced from the best available original document. 
Section

LIST OF FIGURES

LIST OF TABLES

ABSTRACT vi

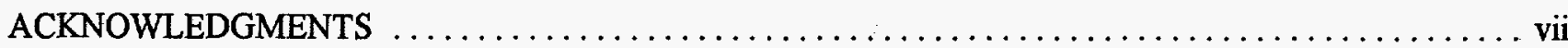

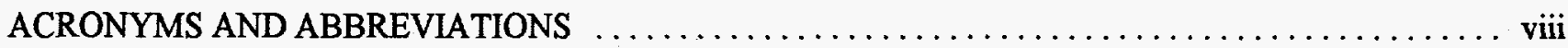

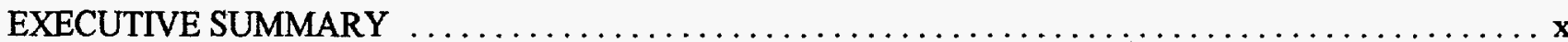

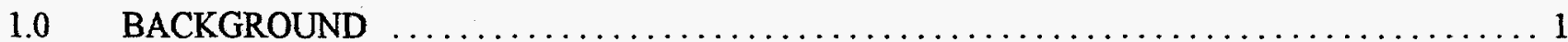

1.1 Sludge Mobilization and Wash Process Description $\ldots \ldots \ldots \ldots \ldots \ldots \ldots \ldots \ldots$

$1.2 \quad$ Sludge Mobilization and Wash System Implementation $\ldots \ldots \ldots \ldots \ldots \ldots \ldots \ldots \ldots$

2.0 SLUDGE MOBILIZATION AND WASH SYSTEM DESIGN $\ldots \ldots \ldots \ldots \ldots \ldots \ldots \ldots \ldots \ldots$

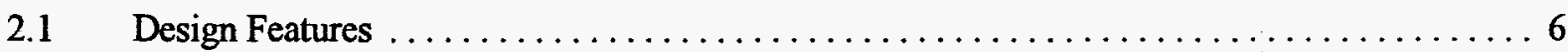

$2.2 \quad$ Sludge Mobilization and Wash System Components $\ldots \ldots \ldots \ldots \ldots \ldots \ldots \ldots \ldots \ldots$

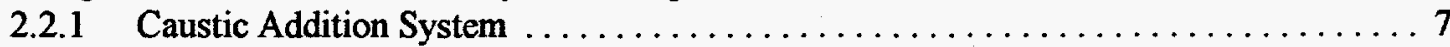

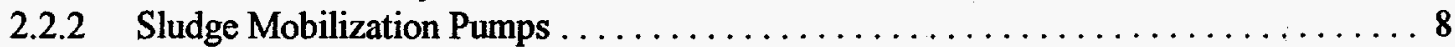

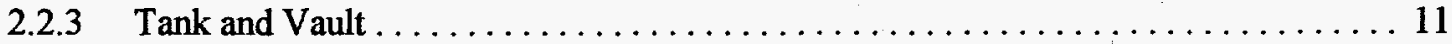

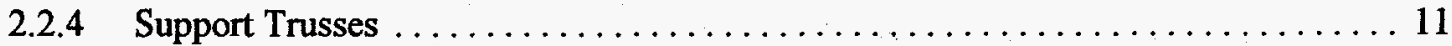

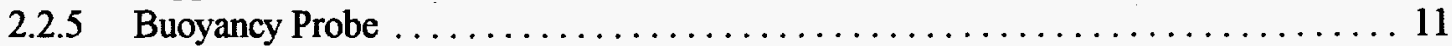

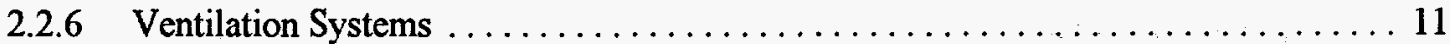

3.0 SLUDGE MOBILIZATION AND WASH SYSTEM OPERATION $\ldots \ldots \ldots \ldots \ldots \ldots \ldots \ldots \ldots$

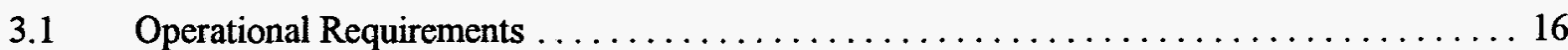

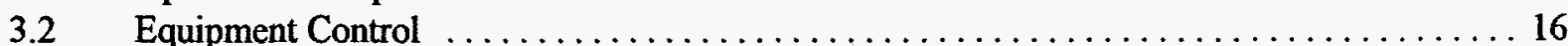

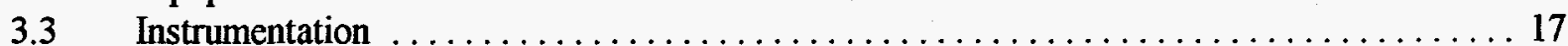

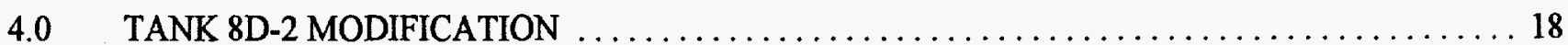

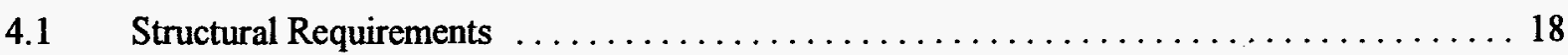

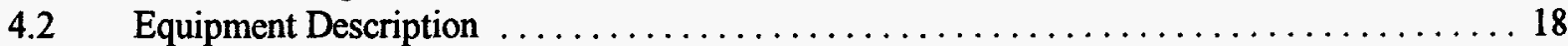

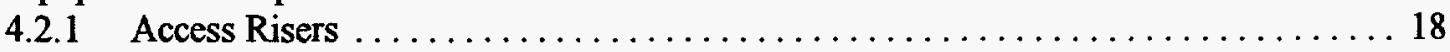

4.2.2 Additional Confinement Barriers . . . . . . . . . . . . . . . . . 19

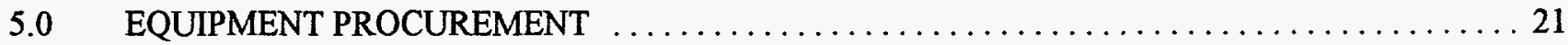


$\underline{\text { Section }}$

6.0 EQUIPMENT INSTALLATION

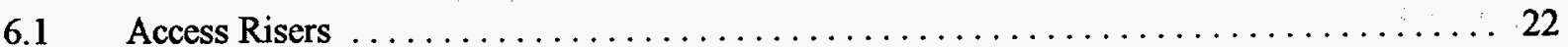

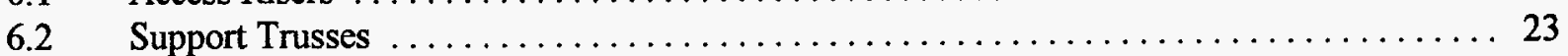

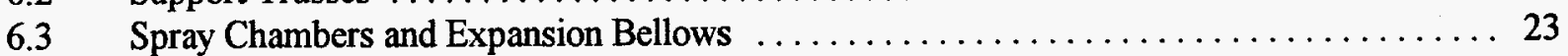

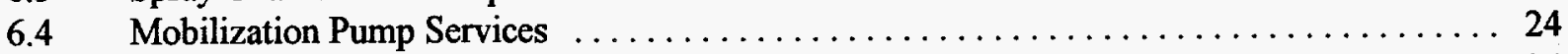

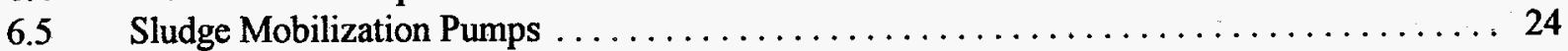

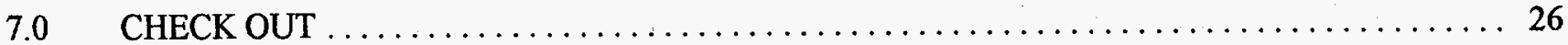

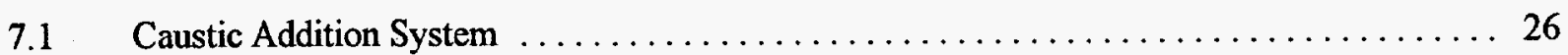

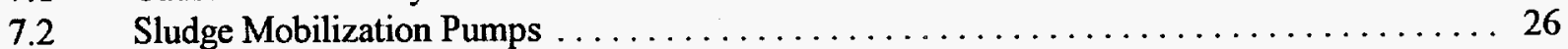

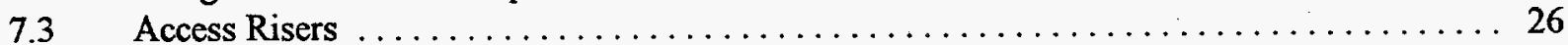

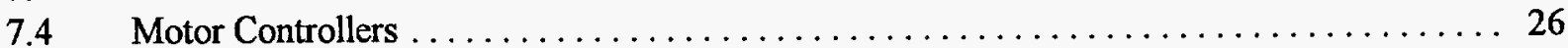

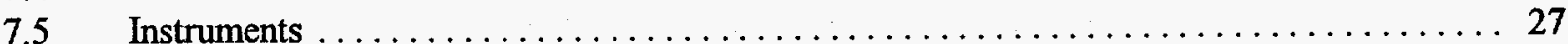

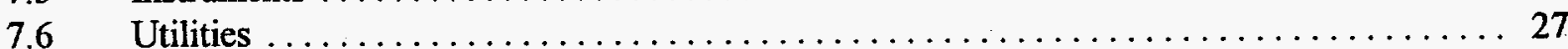

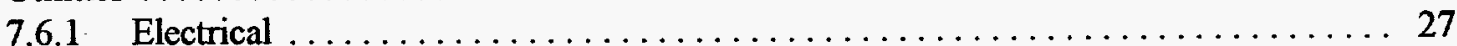

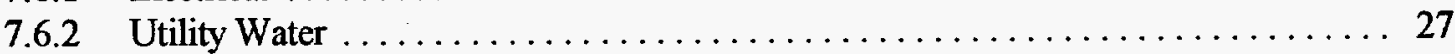

8.0 PROBLEMS ENCOUNTERED AND LESSONS LEARNED $\ldots \ldots \ldots \ldots \ldots \ldots \ldots \ldots \ldots$

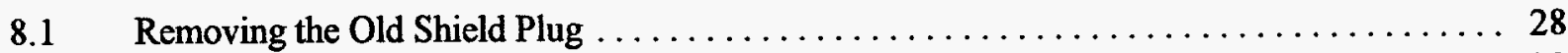

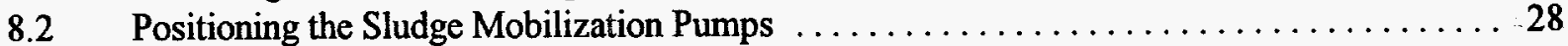

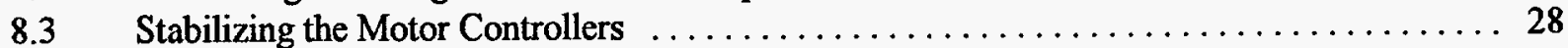

8.4 Preventing Mechanical Seal Leakage . . . . . . . . . . . . . . . . . . . . 29

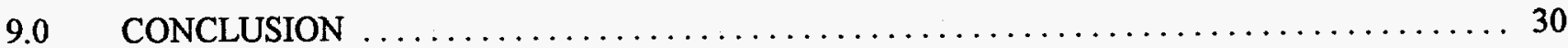

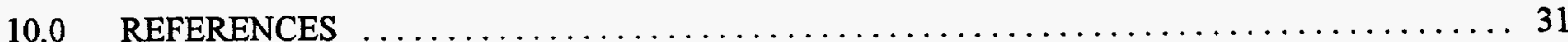




\section{LIST OF FIGURES}

Figure

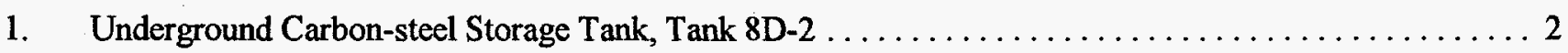

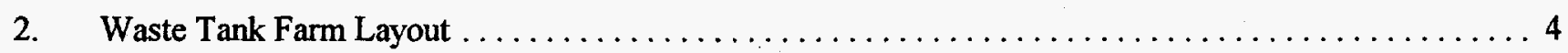

3. Bottom View of Tank 8D-2 Sludge Mobilization Pump Shaft Assembly $\ldots \ldots \ldots \ldots \ldots \ldots \ldots$

4. Top View of Tank 8D-2 Sludge Mobilization Pump Assembly $\ldots \ldots \ldots \ldots \ldots \ldots \ldots \ldots \ldots$

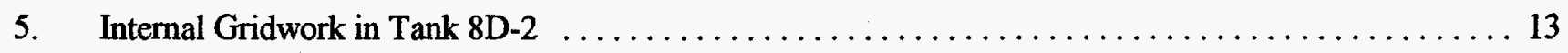

6. Sludge Mobilization Pump Support Truss Structure $\ldots \ldots \ldots \ldots \ldots \ldots \ldots \ldots \ldots \ldots \ldots \ldots$

7. Schematic of Permanent Ventilation System and Waste Tank Farm Ventilation System . . . . . . . . 15

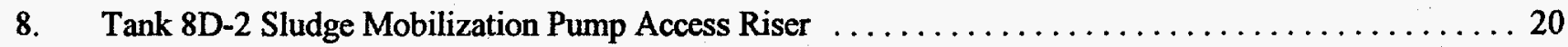

\section{LIST OF TABLES}

Table

1. Chemical Composition of Tank $8 D-2$ Sludge 


\begin{abstract}
PUREX high-level waste (HLW) is contained at the West Valley Demonstration Project (WVDP) in an underground carbon-steel storage tank. The HLW consists of a precipitated sludge and an alkaline supernate. This report describes the system that the WVDP has developed and implemented to resuspend and wash the HLW sludge from the tank. The report discusses Sludge Mobilization and Wash System (SMWS) equipment design, installation, and testing. The storage tank required modifications to accommodate the SMWS. These modifications are discussed as well.
\end{abstract}




\section{ACKNOWLEDGMENTS}

The authors would like to thank their respective departments, Vitrification Facility Engineering and Procedures and Publications Management, for tolerating the authors during the writing of this Topical Report. The authors would like to specially thank Marjorie Dziak for typing and Helene Houston for editing portions of the report. 


\section{ACRONYMS AND ABBREVIATIONS}

$\mathrm{AC}$

$\mathrm{AE}$

ALARA

ASME

C

cfm

$\mathrm{cm}$

CSS

$\mathrm{DC}$

D\&D

DOE

DOE-ID

dpm

F

fpm

$\mathrm{ft}$

gpm

$\mathrm{hr}$

HEPA

hp

HLW

$\mathrm{Hz}$

IRTS

$\mathrm{kg}$

$\mathrm{kN}$

$\mathrm{kPa}$

$\mathrm{kW}$

$\mathrm{lb}$

lpm

LWTS

m

MIG

NQA

PCV

ppm

psi
Alternating Current

Architectural Engineering

As Low As Reasonably Achievable

American Society of Mechanical Engineers

Centigrade

Cubic Feet per Minute

Centimeter

Cement Solidification System

Direct Current

Decontamination and Decommissioning

Department of Energy

Department of Energy - Idaho Operations

Disintegrations per Minute

Fahrenheit

Feet per Minute

Feet

Gallons per Minute

Hour

High Efficiency Particulate Air

Horsepower

High-level Waste

Hertz

Integrated Radwaste Treatment System

Kilogram

Kilonewton

Kilopascal

Kilowatt

Pound

Liters per Minute

Liquid Waste Treatment System

Meter

Metal Inert Gas

Nuclear Quality Assurance

Pressure Control Valve

Parts per Million

Pounds per Square Inch 


\section{ACRONYMS AND ABBREVIATIONS (continued)}

$\begin{array}{ll}\text { psig } & \text { Pounds per Square Inch Gauge } \\ \text { PVS } & \text { Permanent Ventilation System } \\ \text { rad } & \text { Radiation Absorbed Dose } \\ \text { RHO } & \text { Rockwell Hanford Operations } \\ \text { rpm } & \text { Revolutions per Minute } \\ \text { sec. } & \text { Second } \\ \text { SMWS } & \text { Sludge Mobilization and Wash System } \\ \text { SRL } & \text { Savannah River Laboratory } \\ \text { STS } & \text { Supernatant Treatment System } \\ \text { V\&S } & \text { Ventilation and Services } \\ \text { VOG } & \text { Ventilation Off-gas } \\ \text { WNYNSC } & \text { Western New York Nuclear Service Center } \\ \text { WTF } & \text { Waste Tank Farm } \\ \text { WTFVS } & \text { Waste Tank Farm Ventilation System } \\ \text { WVDP } & \text { West Valley Demonstration Project } \\ \text { WVNS } & \text { West Valley Nuclear Services Company }\end{array}$




\section{EXECUTIVE SUMMARY}

The West Valley Demonstration Project Act directed the United States Department of Energy (DOE) to develop and demonstrate technology for the safe removal, processing, solidification, and transportation of alkaline and acidic high-level radioactive wastes at the Western New York Nuclear Service Center. The 2,200,000 liters (560,000 gallons) of high-level waste (HLW) resulted from PUREX fuel reprocessing operations performed by Nuclear Fuel Services, Inc., from 1966 to 1972. In 1981, the DOE selected West Valley Nuclear Services (WVNS) Company, Inc., a subsidiary of Westinghouse Electric Corporation, as the prime contractor for West Valley Demonstration Project (WVDP) operations.

The WVDP has developed a vitrification process for converting the HLW into borosilicate glass. The HLW had two layers: a precipitated sludge and an alkaline supernatant. To reduce the total volume of glass produced, the WVDP is pre-processing the HLW. The WVDP has developed a Sludge Mobilization and Wash System (SMWS) to pre-process the sludge, which is contained in an underground carbon-steel storage tank, Tank 8D-2.

The SMWS was designed to mobilize metallic oxides and salt crystals in the sludge by adding a dilute caustic solution and resuspending the sludge. A series of five low-pressure, high-flow, long-shafted centrifugal pumps located near the bottom of Tank 8D-2 are used to agitate the tank contents and resuspend the settled sludge solids. Once the sludge has been mobilized, it will be removed from Tank 8D-2 and transported to the Vitrification Facility as melter feed. The salts may affect the operational capacity of the Vitrification Facility melter; therefore, several wash cycles are necessary to effectively remove the salts from the sludge.

The SMWS was designed in accordance with the WVDP directive to maximize the use of existing facilities. Tank 8D-2 resides in a Waste Tank Farm comprised of four tanks that are contained in three underground vaults (Tanks 8D-3 and 8D-4 are contained in the same vault). Tank 8D-1 serves as a spare to Tank 8D-2.

The design, installation, and operation of the SMWS incorporates process components that are essential for preparing and transporting the contained HLW to the Vitrification Facility. The WVDP is implementing these tasks in four phases: modifying Tank 8D-2 so that it can accommodate the SMWS, and processing and delivering the supernatant to the Integrated Radwaste Treatment System (IRTS); mobilizing and washing the sludge; mixing the washed sludge with process wastes contained in Tank 8D-1 and Tank 8D-4 and storing the mixture in Tank 8D-2; and resuspending and mixing the waste mixture in Tank 8D-2 and transferring it to the Vitrification Facility.

The WVDP used a one-sixth scale model of Tank 8D-2 and a simulated sludge to determine the most efficient method for resuspending and removing the sludge from the HLW waste storage tank. The one-sixth scale model studies were based on full-scale studies performed at the Savannah River Laboratory. The SMWS incorporates the following design features: removal of equipment loads from the tank structure; central monitoring and control; independent ventilation for tank access; maintainable HLW tank containment; and remote removal and replacement of components in radioactive service.

The key components of the SMWS are the Caustic Addition System and the sludge mobilization pumps. SMWS operations are performed within Tank 8D-2. Trusses were installed over the tank vault to support the sludge mobilization pumps. Tank 8D-2 was structurally modified to house the SMWS: openings (access risers) were made in the tank so that the tank interior could be accessed. Five pumps, as well as a buoyancy probe, penetrate the top of the tank through these openings. The Waste Tank Farm Ventilation System and the Permanent Ventilation System process exhaust air from Tank 8D-2. 
The sludge mobilization pumps had to be lowered into their final position in Tank 8D-2 before they could fully mobilize the sludge. Lowering the pumps involved resuspending the settled sludge layer and gradually lowering the pumps into the tank. Once the five pumps were in their final position, they were operated at full speed and rotated 360 degrees in the clockwise direction while the dilute caustic solution was added. The pumps were continuously operated for four hours to ensure that the sludge and caustic were thoroughly mixed.

In order to operate, the SMWS requires 370 to $560 \mathrm{~kW}(500$ to $750 \mathrm{hp})$ and seal water, which is supplied by the Plant Utility Water Supply System. The mobilization pumps are operated from variable speed controllers and adjustable frequency invertor drives. SMWS operations are monitored with pump seal water supply instrumentation, sludge mobilization pump operating variable indicators, and radiation detectors. The SMWS also incorporates instrumentation for monitoring the contents of Tank 8D-2. These instruments include density indicators and a buoyancy probe.

The internal structure of the tank was less than ideal for the removal of an insoluble sludge; Tank 8D-2, therefore, had to be modified to permit the installation of mobilization equipment and the transfer of HLW waste from the tank. Nine access risers are used to penetrate Tank 8D-2. Only one of the risers was constructed with the tank. The eight additional risers, as well as some flexible expansion bellows and spray chambers, had to be installed.

All equipment and instrumentation for the SMWS were selected and purchased in compliance with the WVDP Quality Assurance Program. Detailed equipment specifications were prepared by the WVDP and issued for competitive bidding.

Installation of the SMWS components was performed by the WVDP and outside subcontractors. The equipment installations that involved Tank 8D-2 access were all performed by specially trained WVDP personnel using remote installation techniques. Equipment installation began with the installation of the new access risers in Tank 8D-2. After all the access risers were installed in the tank roof, the installation of the pump support trusses began. The next components installed were the spray chambers and expansion bellows. After the access risers, support trusses, and riser-to-truss connections were complete, the mobilization pump support services were installed. The service equipment consists of the electrical conduit and cable, utility water piping and valves, system instrumentation, and pump weather enclosure and heater. The sludge mobilization pumps were the last component installed.

During SMWS check out, the WVDP verified that the installation of the system components was accomplished in accordance with the system design drawings, installation specifications, and work procedures. The SMWS check out also included a pre-operational test program, which consisted of three check outs: factory, field, and start up. The Caustic Addition System, mobilization pumps, access risers, motor controllers, instrumentation, and utilities were all checked and verified.

Removing the original access riser shield plug, positioning the mobilization pumps, stabilizing the motor controllers, and preventing mechanical seal leakage all required innovative solutions.

The pre-operational test program verified that the system operates as intended and meets the equipment design objectives. Once all five pumps were lowered into their final position, the pumps were run continuously for 72 hours to dissolve the salts and wash them from the sludge. After this run, samples of the liquid contents of Tank 8D-2 were taken and the salt concentrations were analyzed. The first sludge wash in Tank 8D-2 was completed. 


\subsection{BACKGROUND}

On October 1, 1980, the United States Congress passed the West Valley Demonstration Project Act, Public Law 96-368, which directs the United States Department of Energy (DOE) to perform a waste management demonstration project at the former Western New York Nuclear Service Center (WNYNSC) in West Valley, New York. The purpose of the West Valley Demonstration Project (WVDP) is to develop and demonstrate technology for the safe removal, processing, solidification, and transportation of alkaline and acidic high-level radioactive wastes. The high-level waste (HLW) resulted from PUREX fuel reprocessing operations performed at WNYNSC by Nuclear Fuel Services, Inc., from 1966 to 1972. In 1981, the DOE selected West Valley Nuclear Services Co., Inc., (WVNS) a subsidiary of Westinghouse Electric Corporation, as the prime contractor for WVDP operations.

There are 2,200,000 liters (560,000 gallons) of HLW waste contained at WNYNSC in an underground carbonsteel storage tank, Tank 8D-2 (Figure 1). When the West Valley Demonstration Project began, the HLW consisted of a precipitated sludge layer and an alkaline supernatant layer. The WVDP has developed a vitrification process for converting the HLW into borosilicate glass (Chapman, 1988). To reduce the total volume of glass produced, the WVDP is pre-processing the HLW.

Pre-processing the supernatant entails: decontaminating the supernatant by removing Cesium-137, the major radioactive ion in solution, with the Supernatant Treatment System (STS)(Ploetz, 1988); evaporating the decontaminated supernatant into a concentrate with the Liquid Waste Treatment System (LWTS)(Baker, 1989); encapsulating the concentrate in cement drums with the Cement Solidification System (CSS)(Jezek, 1988); and storing the cement drums as low-level waste in the Drum Cell, pending a decision on ultimate disposal. Together, these four facilities form the WVDP Integrated Radwaste Treatment System (IRTS).

The WVDP also has developed a Sludge Mobilization and Wash System (SMWS) to pre-process the sludge in Tank 8D-2. The SMWS was designed to resuspend and remove the sludge from Tank 8D-2 and transport it to the Vitrification Facility where it will be mixed with glass formers and converted into borosilicate glass. The WVDP performed on-site tests with a one-sixth scale model of Tank 8D-2 to demonstrate that the sludge could be resuspended and removed from the tank bottom using multiple mixing pumps, as demonstrated with full-scale equipment at other DOE facilities (Schiffhauer, 1987).

The sludge is predominately comprised of settled metallic oxides and hydroxides (Table 1), salt crystals, and soluble interstitial salts. The SMWS was designed to remove the soluble interstitial salts and salt crystals from the PUREX sludge by adding a dilute caustic solution and mobilizing the sludge. The caustic suppresses actinide solubility while washing the sludge and dissolving the salt crystals. The soluble salts and salt crystals may affect the operational capacity of the Vitrification Facility melter; therefore, several wash cycles are necessary to effectively remove these metallic oxides from the sludge. The IRTS will process the resultant liquid, the sludge wash solution. The washed sludge will be contained in Tank 8D-2 until it is transported to the Vitrification Facility and used as melter feed.

The SMWS was designed in accordance with the West Valley Demonstration Project directive to maximize the use of existing facilities (Skillern, 1986). Tank 8D-2 was structurally modified to house the SMWS by cutting openings in the tank so that the tank's interior could be accessed. Tank 8D-2 resides in a Waste Tank Farm (WTF) built by the Bechtel Corporation for the Western New York Nuclear Service Center. The WTF is comprised of four tanks contained in three underground vaults (Tanks 8D-3 and 8D-4 are contained in the same vault). Tank 8D-1 serves as a spare to Tank 8D-2. Figure 2 shows the WTF layout and the placement of the access openings in Tank 8D-2.

This report describes the modifications to Tank 8D-2 that were required to accommodate the SMWS, the equipment that was used to make the modifications, and the installation and check out of the equipment. 


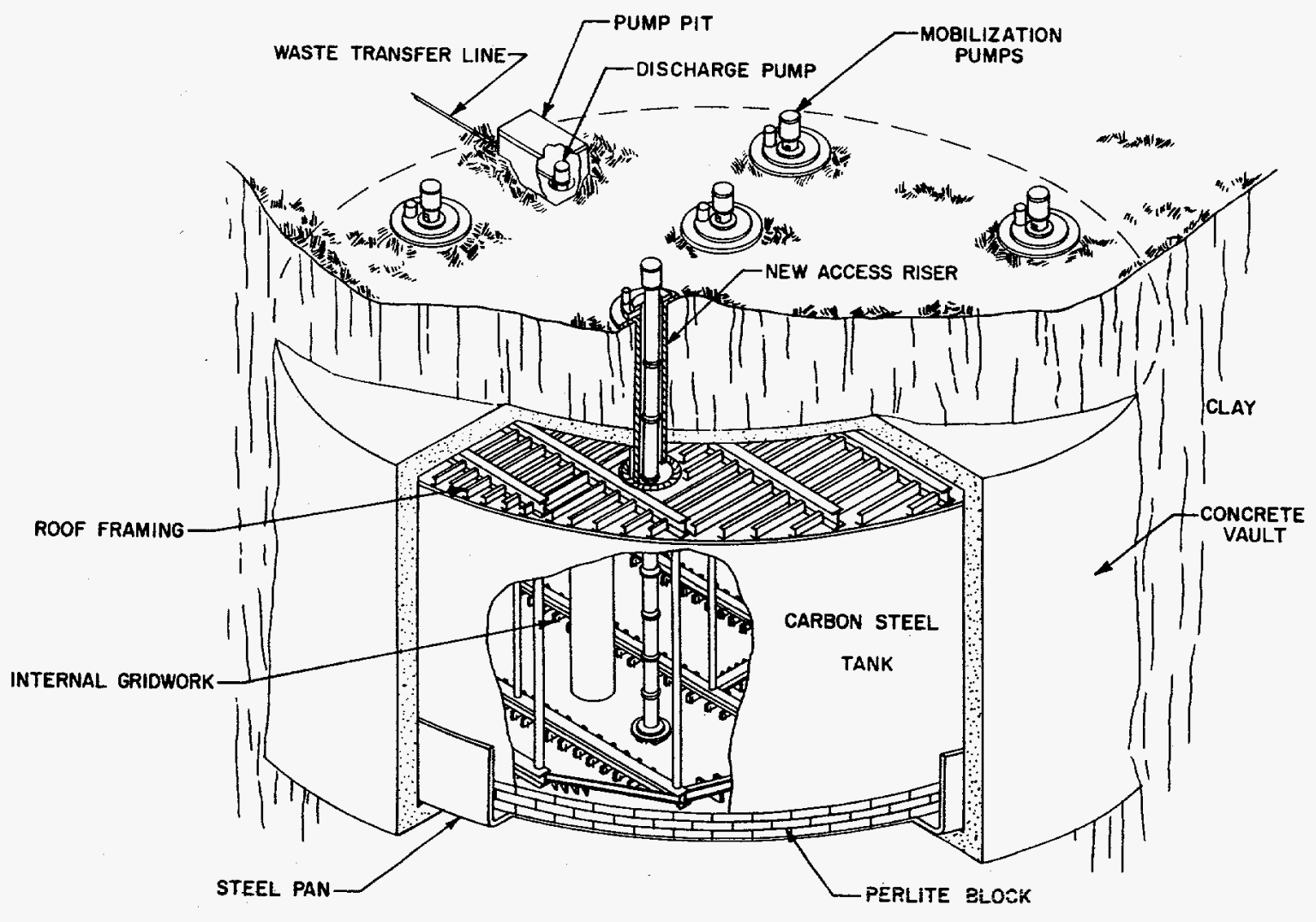

Figure 1. Underground Carbon-steel Storage Tank, Tank 8D-2 
Table 1. Chemical composition of Tank 8D-2 Sludge (Eisenstatt, 1986)

\section{Compound}

$\mathrm{Fe}(\mathrm{OH})_{3}$

$\mathrm{FePO}_{4}$

$\mathrm{Al}(\mathrm{OH})_{3}$

$\mathrm{AlF}_{3}$

$\mathrm{MnO}_{2}$

$\mathrm{CaCO}_{3}$

$\mathrm{UO}(\mathrm{OH})_{2}$

$\mathrm{Ni}(\mathrm{OH})_{2}$

$\mathrm{SIO}_{2}$

$\mathrm{Zr}(\mathrm{OH})_{4}$ (excluding the fission product zirconium)

$\mathrm{MgCO}_{3}$

$\mathrm{Cu}(\mathrm{OH})_{2}$

$\mathrm{Zn}(\mathrm{OH})_{2}$

$\mathrm{Cr}(\mathrm{OH})_{3}$

$\mathrm{Hg}(\mathrm{OH})_{2}$

Fission Products

$\mathrm{SrSO}_{4}$

$\mathrm{Y}(\mathrm{OH})_{3}$

$\mathrm{Zr}(\mathrm{OH})_{4}$

$\mathrm{Ru}(\mathrm{OH})_{4}$

$\mathrm{Rh}(\mathrm{OH})_{4}$

$\mathrm{Pd}(\mathrm{OH})_{2}$

$\mathrm{AgOH}$

$\mathrm{Cd}(\mathrm{OH})_{2}$

$\operatorname{In}(\mathrm{OH})_{3}$

$\mathrm{Sn}(\mathrm{OH})_{4}$

$\mathrm{Sb}(\mathrm{OH})_{3}$

$\mathrm{BaSO}_{4}$

$\mathrm{La}(\mathrm{OH})_{3}$

$\mathrm{Ce}(\mathrm{OH})_{3}$

$\mathrm{Pr}(\mathrm{OH})_{3}$

$\mathrm{Nd}(\mathrm{OH})_{3}$

$\mathrm{Pm}(\mathrm{OH})_{3}$

$\mathrm{Sm}(\mathrm{OH})_{3}$

$\mathrm{Eu}(\mathrm{OH})_{3}$

$\mathrm{Gd}(\mathrm{OH})_{3}$

\section{Total $\mathrm{kg}$ in Sludge}

66040.0

6351.0

5852.0

536.0

4581.0

3208.0

3087.0

1088.0

1263.0

159.0

826.0

376.0

128.0

65.0

23.0

217.0

103.0

805.0

458.0

79.0

34.0

0.7

1.7

0.3

2.5

0.7

303.0

185.0

354.0

170.0

621.0

1.5

143.0

7.5

1.7

35.0

37.0

28.0

0.4

Total

97172.0 


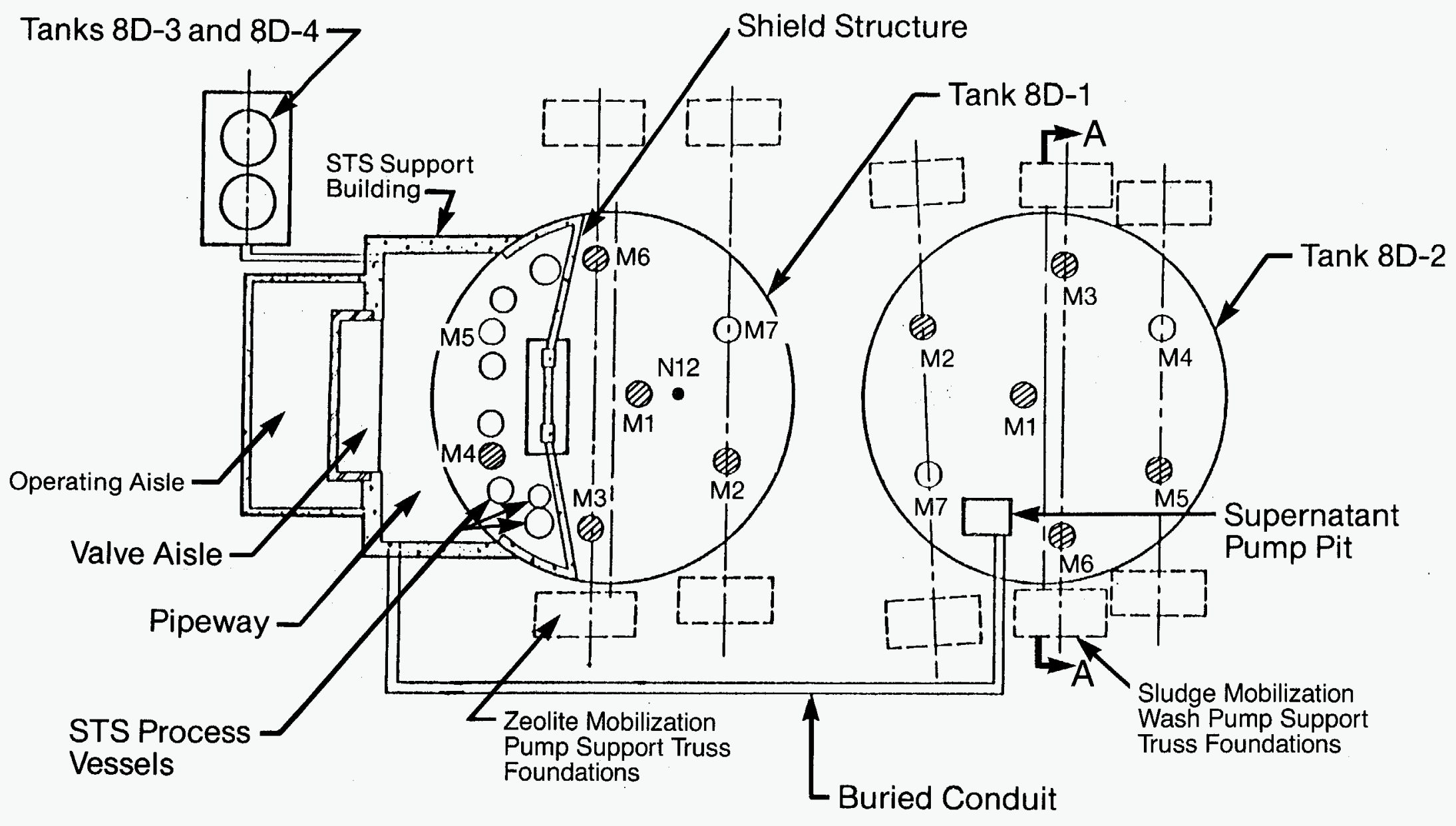




\subsection{Sludge Mobilization and Wash Process Description}

The SMWS adds a dilute caustic solution to Tank 8D-2. Laboratory testing with actual sludge has shown that water by itself dissolves some plutonium and uranium in addition to the sulfate salt crystals. Adding a dilute caustic solution to the sludge greatly reduces plutonium and uranium dissolution (Bray, 1990). Once the dilute caustic solution is added, a series of five low-pressure, high-flow, long-shafted centrifugal pumps located near the bottom of Tank 8D-2 are used to agitate the tank contents and resuspend the settled sludge solids. The mobilization pumps mix the solids and the added caustic solution, accelerating the dissolution of salt crystals. The exact duration of mixing is determined by sampling the liquid periodically and tracking the change in salt concentration in the solution. After the salt concentration has leveled off, the mixing is stopped and the solids are allowed to settle. Once the solids have settled, the wash solution is drawn from Tank 8D-2 with a floating suction removal pump and transferred to the IRTS for processing.

\subsection{Sludge Mobilization and Wash System Implementation}

The design, installation, and operation of the SMWS incorporates process components that are essential for preparing and transporting the stored HLW to the Vitrification Facility. The WVDP is implementing these tasks in four phases. Phase I, which began in 1987, entailed: 1) modifying Tank 8D-2 so that it could accommodate the SMWS, and 2) processing and delivering the supernatant to the IRTS. Phase II, which began early in 1991, entails mobilizing and washing the sludge. Phase III will entail mixing the washed sludge with process wastes contained in Tank 8D-1 and Tank 8D-4 and storing the mixture in Tank 8D-2. Phase IV will entail resuspending and mixing the waste mixture in Tank 8D-2 and transferring it to the Vitrification Facility. 


\subsection{SLUDGE MOBILIZATION AND WASH SYSTEM DESIGN}

Full-scale studies of a method for resuspending HLW tank sludge with supernatant were initially performed by I. E. du Pont de Nemours and Company at the Savannah River Laboratory (SRL). These studies demonstrated that a low-pressure, high-flow waste removal method could successfully resuspend HLW tank sludge. The WVDP used a one-sixth scale model of Tank 8D-2 and a simulated sludge to determine the most efficient method for resuspending and removing the sludge from the tank (Schiffhauer, 1987). The simulated sludge was developed using the results of a Waste Characterization Program instituted at the WVDP (Rykken, 1986). The one-sixth scale model was used to model, at reduced scale, the flow behavior of the equipment used at SRL so that the behavior specific to Tank 8D-2 could be determined. By examining the removal efficiencies of the reduced-scale equipment used in the model, the number and location of the pumps was determined for the final SMWS design.

\subsection{Design Features}

The SMWS design was based on DOE Order 6430.1, General Design Criteria. The Idaho National Engineering Laboratory Architectural Engineering (AE) Standards Manual was used for AE design and the preparation of specific task design criteria. The AE standard is a supplement to 6430.1 and contains more detailed design criteria specific to Department of Energy - Idaho Operations (DOE-ID) facilities. The AE standards also are based on applicable DOE Orders, including DOE-ID supplements, and the national consensus codes and standards.

The SMWS had to incorporate the following design features:

- Removal of equipment loads from the tank structure

- Central monitoring and control

- Independent ventilation for tank access

- Maintainable HLW tank containment

- Remote removal and replacement of components in radioactive service

Pump support trusses were designed to carry both the static and dynamic loads of the sludge mobilization pump assemblies away from the tank and vault.

The SMWS is centrally operated from a control room in the Ventilation and Services (V\&S) Building adjacent to Tank 8D-2. Equipment operations are periodically monitored from this location as well. The tank contents are monitored with density indicators and a buoyancy probe.

The STS Permanent Ventilation System (PVS), which is located in the V\&S Building, was designed to provide ventilation when Tank 8D-2 was accessed to install equipment. The PVS ensures that the tank is maintained under negative pressure relative to the atmosphere so that the required air flow is into, rather than out of, the tank. The minimum air flow required across any tank access opening is $125 \mathrm{ft} / \mathrm{sec}$.

SMWS structural barriers important to the control of radioactivity were designed so that Tank 8D-2 confinement is not compromised by any credible design basis event (e.g., an earthquake).

The SMWS was designed to facilitate the eventual decontamination and decommissioning (D\&D) of the in-tank components. The sludge mobilization pumps, density indicators, and buoyancy probe were all designed to permit semi-remote removal and replacement. 
For ease of decontamination, the SMWS design also incorporates other features. The mobilization pumps were designed to handle a wide range of decontamination fluids and to minimize collection pockets - pits, scratches, gouges, or sharp nipples that could entrap contaminated material. The pump columns were fitted with guides that prevent the flange or other projections from the pump from catching on the tank risers or structure during installation or removal. The pump surfaces below the pump base plate and in contact with the tank process liquid were fabricated from low-carbon stainless steel. All the welded surfaces that come in contact with the process liquid were ground flush and smooth (to a 63 micro-inch finish). Similarly, the pump volutes were fitted with a line that flushes the volute, impeller, and pump suction screen. A series of spray nozzles were installed in the spray chamber above Tank 8D-2 access openings to flush a mobilization pump as it is removed from the tank. The buoyancy probe also was fabricated from stainless steel and fitted with a spray ring assembly.

\subsection{Sludge Mobilization and Wash System Components}

The key components of the SMWS are the Caustic Addition System and the sludge mobilization pumps. SMWS operations are performed within Tank 8D-2. Trusses were installed over the tank's vault to support the sludge mobilization pumps. Five pumps, as well as the buoyancy probe, penetrate the top of the tank through a series of openings called access risers. These access risers are a modification to the original Tank 8D-2 design. The sludge mobilization pump motors are mounted at the top of the risers. A fiberglass weather enclosure contains the motor and utilities for each pump.

All SMWS components in radioactive service are located in Tank 8D-2. The tank is, therefore, maintained under negative pressure relative to the atmosphere by the Waste Tank Farm Ventilation System (WTFVS); this pressure ensures that air leakage is into, rather than out of, the tank. The WTFVS also processes and filters this exhausted air. The STS Permanent Ventilation System (PVS), which is located in the V\&S Building adjacent to Tank 8D-2, provides ventilation for accessing the tank. The V\&S Building also houses support equipment for the SMWS, such as variable speed motor controllers and instrument indicators.

\subsubsection{Caustlc Addition System}

A tanker truck delivers approximately 4,500 gallons of liquid sodium hydroxide (caustic) to the WVDP. The concentration of the caustic is a nominal $20 \%$ by weight. The tanker truck's pump (rather than air pressure) is used to unload and transfer the caustic to Tank 8D-2. The caustic is transferred from outside the Tank Farm where the truck and a truck unload cart are completely enclosed in an inflatable berm. The unload cart consists of valves and instruments for controlling and monitoring the caustic. The caustic is pumped to Tank 8D-2 through a cross-linked polyethylene hose and hose quick disconnects. The hose joints are sleeved or wrapped and taped to protect against leakage.

The caustic is received on site, sampled, analyzed, and then, if accepted, transferred to Tank 8D-2. The amount of caustic transferred is measured with a flow totalizer. The resultant change in the level of liquid in Tank 8D-2 is used to verify the amount of caustic transferred. Demineralized water is also added to Tank 8D-2 for sludge washing operations after the caustic solution addition is complete. Excess caustic will always be present in Tank 8D-2. The presence of excess caustic in Tank 8D-2 is ensured by sampling each batch prior to transferring it to the tank. 


\subsubsection{Sludge Mobllization Pumps}

Scale model testing demonstrated that five pumps would be sufficient to mix the settled solids into a transportable slurry. Deep-well, long-shafted centrifugal pumps used in the agriculture industry were selected as the basis of the mobilization pump design. The SMWS uses low-pressure, high-flow centrifugal pumps to discharge beneath the complex bottom gridwork of the tank and to scour the tank bottom and internal structure with the mobilized sludge.

Each pump is supported from a $15-\mathrm{m}$ (50-ft) long column constructed from pieces of $35.6 \mathrm{~cm}$ (14 inch) in diameter tubular stainless steel pipe. These columns house the pump drive shaft (Figure 3 ). Each column is filled with water to lubricate the shaft bearings and to provide radiation shielding. The column of water exerts static pressure on the lower column seal to prevent the tank contents from entering the pump columns.

At the top of the column, the pump shaft has a durametallic (type RO) cartridge mechanical seal. The seal is equipped with a special seal gland arrangement that acts as a secondary containment between the column and the atmosphere. Some leakage of column water must occur to cool and lubricate the seal. Both the seal and the seal gland outlets are piped to the tank through the access risers. The seal between the lower column and pump volute is a flexible bellow seal that enables vertical shaft movement.

The volutes are used to encase the pump impellers. These components are positioned at the bottom of Tank 8D-2 approximately $30 \mathrm{~cm}$ (12 inches) from the tank floor. The volutes have two opposed, tangential nozzles that are $3.8 \mathrm{~cm}$ ( 1.52 inches) in diameter. These nozzles provide agitation by using the fluid in the tank to resuspend the sludge. Each nozzle discharges approximately $25.4 \mathrm{~cm}$ (10 inches) from the tank floor. The pumps operate at a flow rate of $2,300 \mathrm{lpm}(600 \mathrm{gpm})$ from each nozzle. The nozzles are continuously rotated 360 degrees at a rotational speed of $0.5 \mathrm{rpm}$.

Each pump has a $110-\mathrm{kW}(150 \mathrm{hp})$ motor that is vertically mounted at the top of the pump shaft, which is housed above the tank (Figure 4). The pump shaft-to-motor coupling is a flanged type with variable axis adjustment. The variable adjustment enables a SMWS operator to set the pump impeller-to-volute clearance from outside the tank.

Each pump is mounted on an assembly that rotates the pump 360 degrees in both the clockwise and counterclockwise direction. The rotating assembly consists of a rotating bearing and gear motor mounted on a bearing base plate.

Each pump rests on split support spacers that vary in thickness to accommodate for variations in the elevation of the tank floor. A 10.2 to $15.2-\mathrm{cm}$ (4 to 6 -inch) difference in elevation exists at the tank floor. The variations are caused by a slope in the tank floor, which resulted when water filled the area excavated for the tank and vault construction and shifted the underlying till. Since the pumps are all $15.2 \mathrm{~m}(50 \mathrm{ft})$ long, support spacers were designed to position each pump discharge nozzle at the same distance from the tank floor.

A slip-ring assembly connects the power cables to the motor leads and enables the pump motor to rotate. An electrical cable conduit attached to the pump support truss holds the slip-ring assembly stationary while the motor rotates.

When the pump is not operating, the motor and slip-ring assembly are heated to prevent liquid condensation from forming inside the units. Each slip ring and motor has space heaters that are energized when the pump is shut down. The motor controllers have a power source for energizing the heaters. Each time the motors are shut down at the controllers, the heaters are automatically activated. 


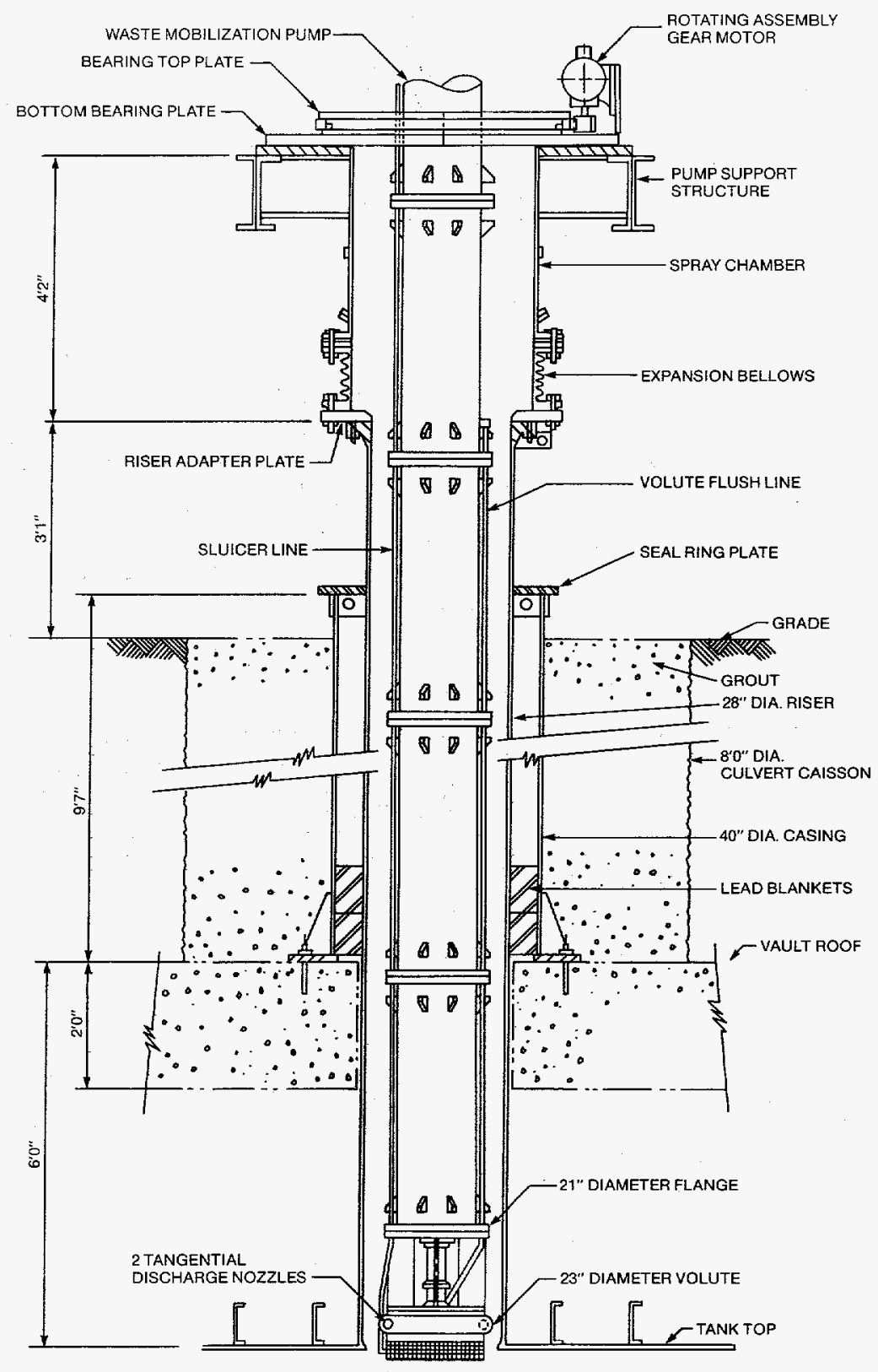

Waste Mobilization Pump Installation

Figure 3. Bottom View of Tank 8D-2 Sludge Mobilization Pump Shaft Assembly 


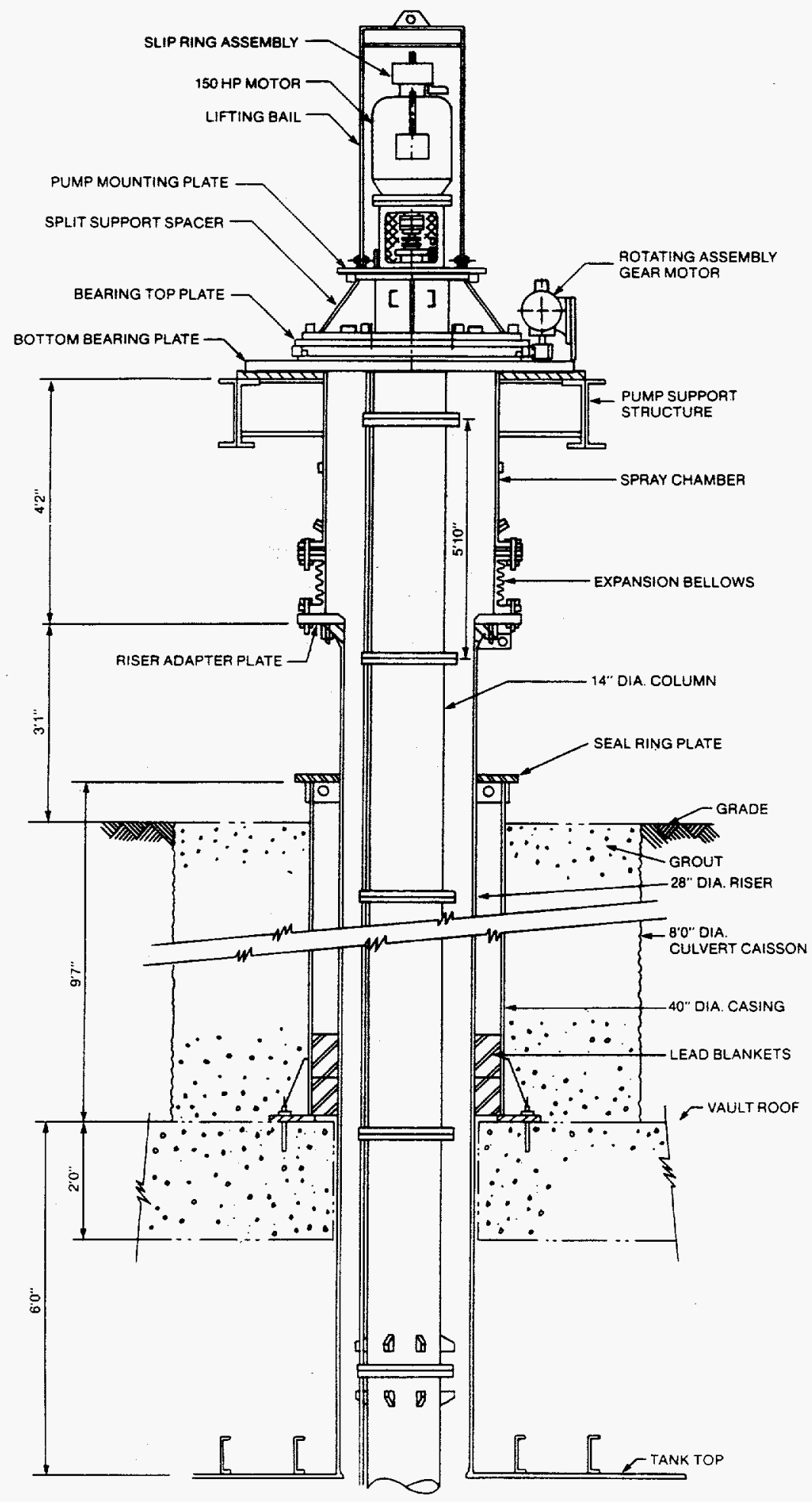

Figure 4. Top View of Tank 8D-2 Sludge Mobilization Pump Assembly 
When the motors are energized by the controllers, the heaters are automatically turned off. At no time are the heaters on while the pumps are operating.

\subsubsection{Tank and Vault}

Tank 8D-2 is a carbon-steel tank $21 \mathrm{~m}(70 \mathrm{ft})$ in diameter and $8.3 \mathrm{~m}(27 \mathrm{f}$ ) in height. The side of the tank tapers in thickness from 1.1 to $1.3 \mathrm{~cm}(7 / 16$ to $1 / 2$ inch). The tank roof is $1.1-\mathrm{cm}(7 / 16$-inch) thick and the floor is 1.3 $\mathrm{cm}(1 / 2$ inch). Tank 8D-2 has an elaborate internal gridwork consisting of I-beams an plates supported from the floor by $11 / 2$-inch rods. The tank roof is supported by forty-five $20 \mathrm{~cm}(8 \mathrm{inch})$ in diameter steel columns resting on the I-beam assembly attached to the tank floor (Figure 5). The tank rests on a 12-inch layer of perlite blocks supported by a 7.62-cm (3-inch) layer of pea gravel in a carbon-steel pan (Schiffhauer, 1985).

A 61.0-cm (24-inch) thick concrete vault encloses Tank 8D-2. The vault roof is supported by six $76.2 \mathrm{~cm}$ (30.48 inch) in diameter concrete columns that penetrate the tank roof through six $122.0 \mathrm{~cm}$ (48 inch) in diameter carbon-steel sleeves. The columns are arranged concentrically $488.0 \mathrm{~cm}$ (192 inches) from the tank center. These columns are the greatest obstruction to fluid flow in the tank.

\subsubsection{Support Trusses}

Tank 8D-2 and its vault were not designed for large equipment loads; for this reason, pump support structures were constructed over the tank vault. The pump support structure consists of steel trusses that rest on concrete piers and spread footing foundations (Figure 6). The length of the trusses ranges from 82.0 to 105.0 feet. The pump support structures were designed to carry both the static and dynamic loads of the mobilization pump assemblies away from the tank structure. As a result, none of the mobilization pump loads are imparted to the top of the tank or the concrete vault.

\subsubsection{Buoyancy Probe}

A buoyancy probe was installed in Tank 8D-2 to measure the height of the sludge layer (the solids-liquid interface). The instrument has $\mathrm{a} \pm 1.3-\mathrm{cm}( \pm 1 / 2$-inch) level of accuracy. The buoyancy probe also measures the density of the liquid above the sludge layer. These measurements are used to determine whether any stratification of the liquid phase has occurred and the rate at which the sludge solids are settling. The probe operates based on the concept that the difference in the weight of an object in air and in liquid is equal to the volume of the object multiplied by the density of the liquid in which it is submerged.

The buoyancy probe consists of a stainless-steel weight suspended by a piece of flat tape. The probe is raised and lowered through the M-4 riser in Tank 8D-2 with a DC motor. The probe's weight and location are constantly monitored by a load cell and mechanical totalizer. These components are all contained within a protective housing. A sliding hatch on the bottom of the housing conceals the weight when it is not in use. When the probe is operated, a load cell readout and a variable voltage motor controller are connected to the housing.

\subsubsection{Ventilation Systems}

Exhaust air from Tank 8D-2 is processed and filtered by the Waste Tank Farm Ventilation System (WTFVS). The WTFVS was constructed in the early sixties as part of the original reprocessing plant. The STS Permanent Ventilation System (PVS) provides temporary ventilation for accessing Tank 8D-2. Figure 7 is a schematic of these ventilation systems. 
The WTFVS treats approximately $300 \mathrm{cfm}$ of air from Tanks 8D-1 and 8D-2 by passing it through an air cleaning train. First, the air is passed through a condenser to remove water vapor and cool the tanks. The air is then passed through a knock-out drum and demister to remove entrained liquid. The condensate is returned to Tank 8D-2, while the noncondensibles are passed through a heater and a single HEPA filter and blower. A second cleaning train is connected in parallel with the first to provide continuous exhaust during component maintenance and in the event of off-gas equipment failure. The WTFVS also is connected to a back-up power generator in case of a power failure. After the air is processed by the WTFVS, it is combined with treated effluents from other WVDP activities and monitored at the Main Processing Plant Stack before it is released to the environment.

The PVS is similar to the WTFVS in that it processes exhaust air from Tank 8D-2 by passing the air through an air cleaning train. The train consists of a mist eliminator, heater, roughing filter, and two sets of HEPA filters connected in series. The PVS has a separate stack for releasing processed air. A second train is connected in parallel with the first to provide continuous exhaust during component maintenance and in the event of off-gas equipment failure. The PVS also has a back-up power generator. 


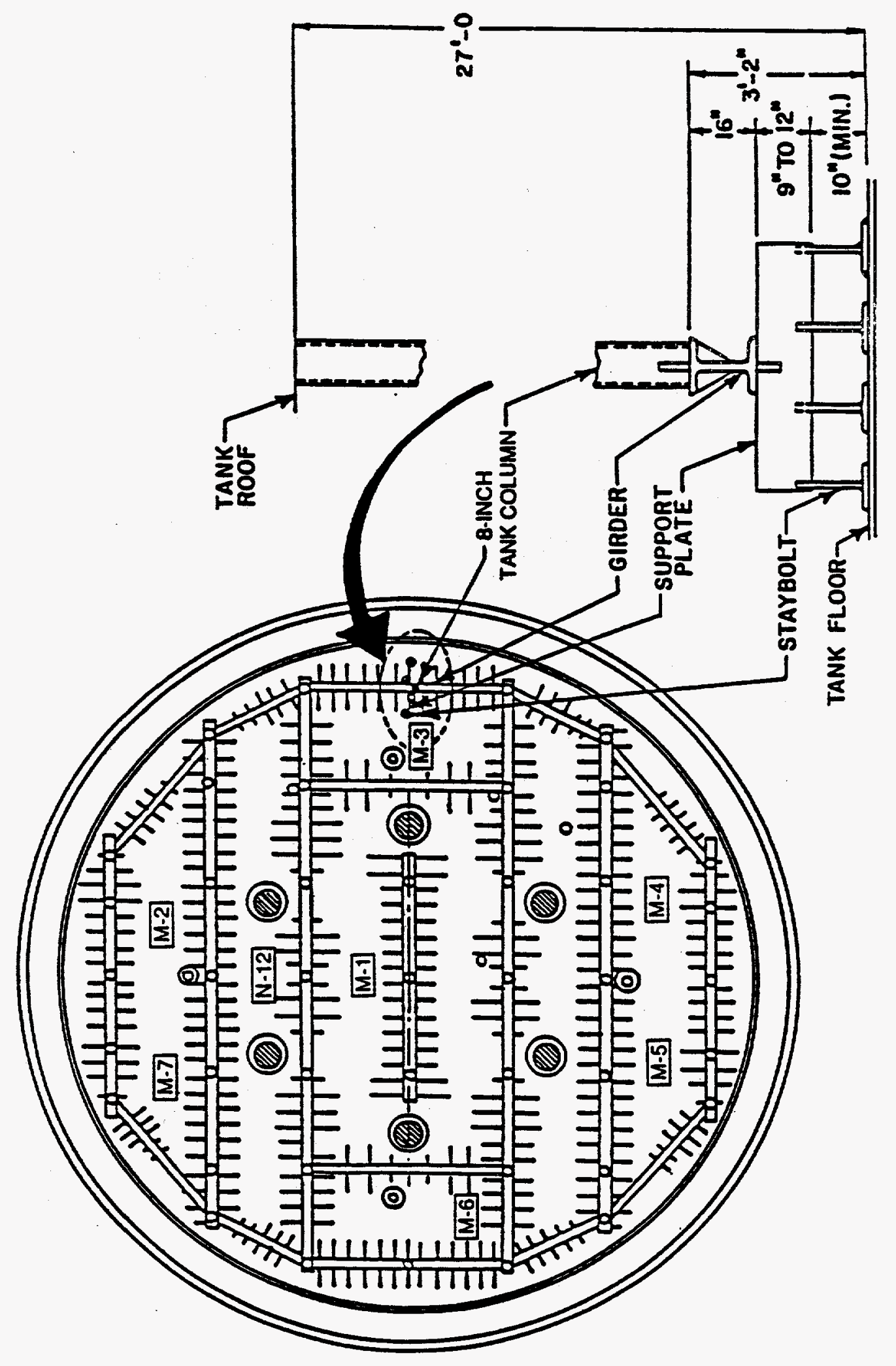

合 


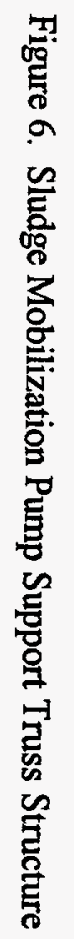

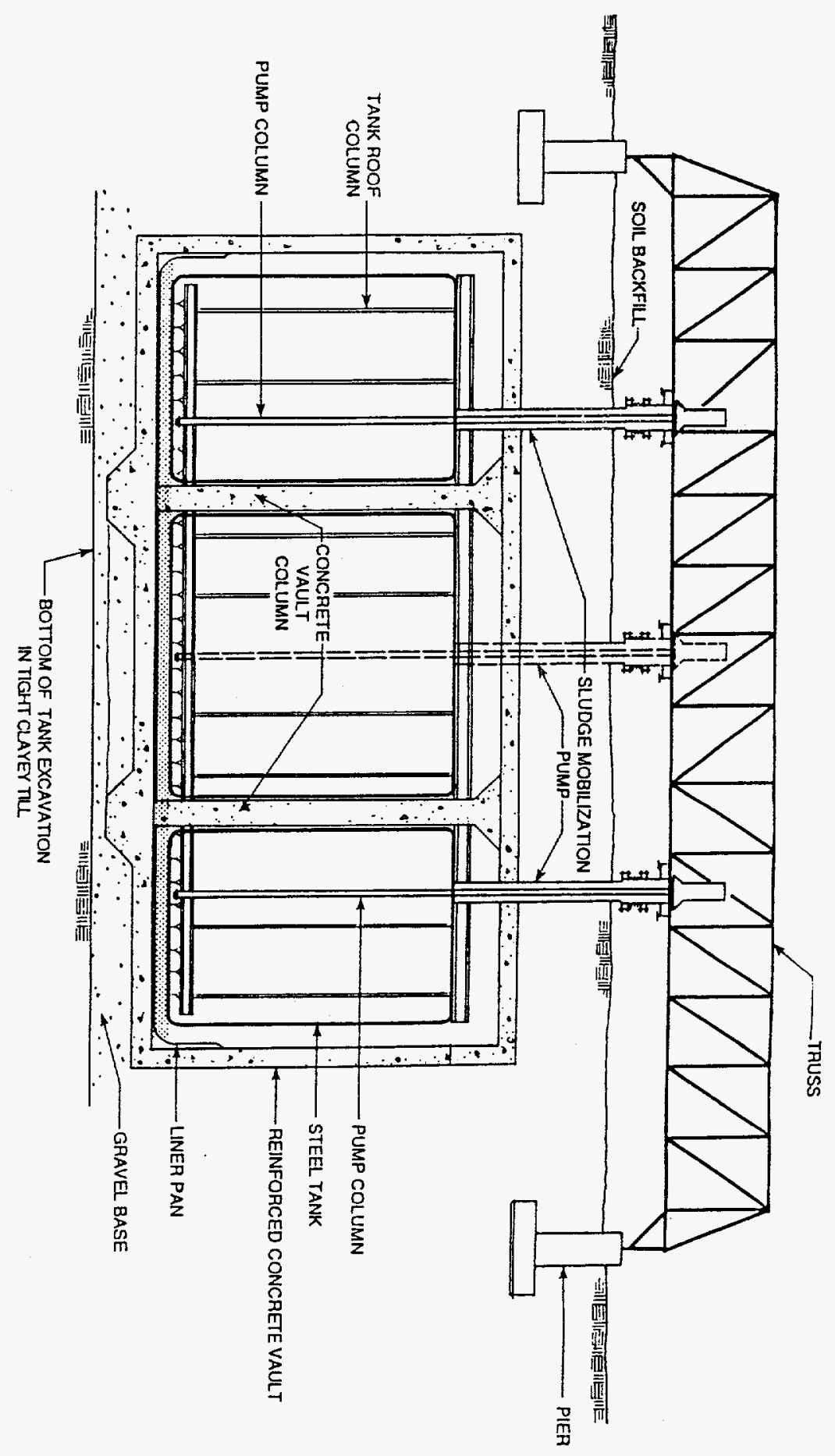




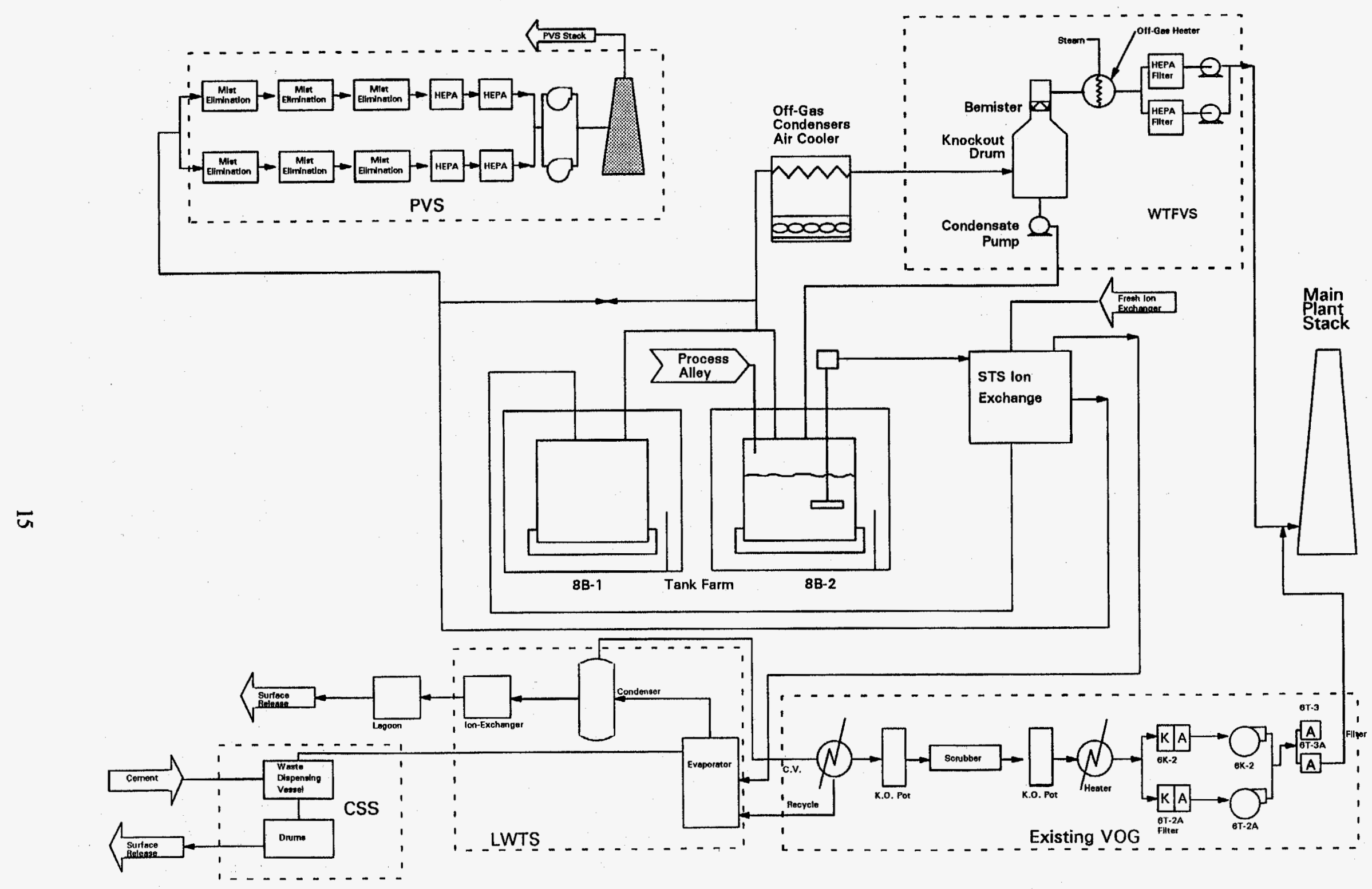

Figure 7. Schematic of Permanent Ventilation System and Waste Tank Farm Ventilation System 


\subsection{SLUDGE MOBILIZATION AND WASH SYSTEM OPERATION}

The sludge mobilization pumps had to be lowered into their final position in Tank 8D-2 before they could be operated at full speed. Lowering the pumps involved resuspending the settled sludge layer and gradually lowering the pumps into the tank. Since the sludge layer obstructed the placement of the pumps, the sludge mobilization pumps were placed on sets of 7.62-cm (3-inch) thick aluminum split shims to set the pump suction above the sludge layer. These shims were temporarily placed between the top of the rotating assembly and the bottom of the split support spacers.

Buoyancy probe measurements were used to lower the pumps from their initial to their final position. The height of the sludge layer was initially measured to establish a base line for the effectiveness of sludge resuspension. After the pumps were operated for a predetermined period of time, the system was shut down and a new measurement was taken. The difference in the sludge layer height was used to determine the number of split shims that had to be removed in order to lower each mobilization pump into its final position. Each pump was lowered into its final position, approximately $15.2 \mathrm{~cm}$ ( 6 inches) from the tank floor, by gradually lifting the pump with a mobile crane and removing shims.

Once the five pumps were in their final position, they were operated at full speed and rotated 360 degrees in the clockwise direction while the caustic was added. The pumps were continuously operated for four hours to ensure that the sludge and the caustic solution were thoroughly mixed. The sludge height and the amount of suspended solids in the liquid were monitored using the buoyancy probes.

A concern over the heat generated from the operation of the five pumps was raised during a Safety Analysis of the SMWS. The possibility of the heat causing the liquid contents of Tank 8D-2 to boil prompted the concern. For this reason, the temperature of Tank 8D-2 was monitored during the operation of the pumps. Heat transfer was estimated and it was concluded that prolonged operation of the pumps would not cause the liquid contents to approach boiling temperature. Control measures were established for pump operations, nevertheless. For example, it was decided that shim removal, which involved accessing the tank, could not be performed unless the temperature of the tank liquid was below $165^{\circ} \mathrm{F}\left(74^{\circ} \mathrm{C}\right)$. This control measure was set to limit the amount of moisture in the air flow to the PVS.

\subsection{Operational Requirements}

The SMWS requires 370 to $560 \mathrm{~kW}$ (500 to $750 \mathrm{hp}$ ). Motor current and voltage are monitored from the control panel in the SMWS Control Room. If a power failure occurs, the SMWS pumps will stop in a fail-safe condition. The mobilization pumps require seal water, which is supplied by the Plant Utility Water Supply System. Seal water pressure and flow are monitored at the pump.

\subsection{Equipment Control}

The SMWS Control Room consists of a series of variable speed controllers for each mobilization pump. The Control Room also contains the motor starters for the mobilization pump rotating assemblies.

The mobilization pumps are operated from variable speed controllers and adjustable frequency invertor drives. These controls enable the pumps to operate over a range of 900 to $1,800 \mathrm{rpm}$. The invertor drives enable soft starting the pumps - starting the pumps at a reduced speed - while maintaining a constant torque on the pump shaft. Soft starting the pumps results in a low start-up power requirement. During pump operations, each pump was started at $60 \%$ speed and then allowed to automatically ramp up to $100 \%$ speed $(1800 \mathrm{rpm})$. The pumps 
were started in succession. When the first pump stabilized, the next one was started. Each pump was started in the same manner as the first until all five pumps were running.

All the sludge mobilization operating variable indicators are mounted on the variable speed controller doors. Key pump variables that can affect the equipment - pump motor amperage, pump seal water pressure, and flow in the pump column - are wired to automatically shut down the pumps if a component fails. Other system variables Tank 8D-2 liquid temperature, WTFVS off-gas temperature, pump enclosure temperature, and radiation level in the pump column - have alarms to alert Operations of a potential hazard. These variables are monitored to maintain safe operations; they do not affect SMWS equipment.

\subsection{Instrumentation}

SMWS operations are monitored with pump seal water supply instrumentation, sludge mobilization pump operating variable indicators, and radiation detectors. These instruments are used to monitor the mobilization pump seal water supply, weather enclosure temperature, motor operating variables, and column water radiation levels. The SMWS also incorporates instrumentation for monitoring the contents of Tank 8D-2, which includes density indicators and a buoyancy probe.

The pump seal water supply instrumentation consists of a pressure control valve (PCV), inlet and outlet pressure gauges, low-pressure switch, high-flow switch, and a pressure relief valve. This instrumentation is used to protect the pump equipment. The PCV regulates the utility water supply pressure and reduces the inlet pressure to the pump seal to $50 \mathrm{psig}$. The pressure gauges are used for verifying the water pressure prior to start up. The lowpressure switch maintains the water pressure at $40 \mathrm{psig}$. The switch does not allow the pump to start if the pressure drops below this value. Similarly, the switch disables the pump during operation if the seal water supply pressure drops below $40 \mathrm{psig}$. The high-flow switch trips at approximately $2 \mathrm{gpm}$. If the pump column or mechanical seal were to leak, the high-flow switch would sense the change in flow and shut down the pump.

The pump motor controllers are equipped with an amperage meter, output volt meter, speed/frequency meter, and elapsed time indicator. Each controller has a high motor amperage trip, incoming low-voltage set-point trip, adjustable ramp speed settings, and critical frequency lockouts. Critical frequencies from 600 to $900 \mathrm{rpm}$ were locked out because large pump vibration displacements were observed at these frequencies.

Radiation detectors are installed at each pump column to monitor the radiation levels in the pipe column at the split support spacer. The monitors have alarms that are set slightly above background and connected to a siren and flashing light on the outside of the pump enclosure.

Density indicators are installed in Tank 8D-2 at different heights to measure the liquid density. These indicators also are used to measure the settling of solids. A buoyancy probe was installed in the tank to indicate the solidsliquid interface between the sludge and liquid layers. The probe also is used to measure the density of these layers. 


\subsection{TANK 8D-2 MODIFICATION}

In the early sixties, when Nuclear Fuel Services built the nuclear fuel reprocessing facility at WNYNSC, storing liquid radioactive waste in an underground steel tank was the liquid-waste disposal method utilized at federal facilities. Following this precedent, Tank 8D-2 was constructed at WNYNSC. A single access riser was installed in the tank for transferring liquid wastes. During the seventies, however, securing long-term permanent isolation of HLW from the biosphere became one of the Federal Government's waste management objectives. For this reason, the HLW contained in Tank 8D-2 had to be removed and treated. The internal structure of the tank was less than ideal for the removal of an insoluble sludge; Tank 8D-2, therefore, had to be modified to permit the installation of mobilization equipment and transfer of HLW waste from the tank.

\subsection{Structural Requirements}

Since Tank 8D-2 was not designed with removal equipment in mind, load limits for the tank modifications restricted equipment design. The steel truss support structures were designed to carry the pump loads and transfer them to the ground away from the vault. The loads of the new access risers were transferred to the vault, where the loads were negligible in comparison to the soil excavated for riser installation. The size of the riser opening in the tank roof was limited so that tank integrity was not compromised under design loads. Dynamic loads from the operation of the mobilization pumps were also evaluated (Gates, 1991). The pump support trusses were designed to act as a relatively stiff platform under lateral seismic loads so that the potentiality of a pump column impacting an access riser or structures inside the tank could be minimized (EBASCO, 1986). To minimize resonance with the pump operating frequencies, a $10-\mathrm{Hz}$ separation was used as the design objective for the support trusses. No restrictions were imposed on the operating frequencies of the pumps to minimize structural resonance that might result from multiple pump operations; however, restrictions were imposed on operating frequencies to minimize the vibration level of the pumps themselves. Load restrictions were also imposed on the construction equipment used for SMWS equipment installation. After installation, the structural modifications to Tank 8D-2 were reanalyzed to verify that their structural integrity was not compromised.

\subsection{Equipment Description}

Nine access risers penetrate Tank 8D-2. Only one of the risers was constructed with the tank. The eight additional risers were installed using remote equipment and techniques (Jackson, 1988). These access risers are the only structural modification to the original Tank 8D-2 design. Flexible expansion bellows and spray chambers complete the tank confinement barriers between the access risers and the pump support trusses.

\subsubsection{Access Risers}

The 5.5-m (18-foot) access risers above Tank 8D-2 permit the insertion of pumps as well as sampling and monitoring equipment into the tank. These risers are constructed of $61.0 \mathrm{~cm}(24$ inch) in diameter standard pipe. The risers extend from $0.91 \mathrm{~m}(3 \mathrm{ft})$ above grade down through the vault roof to the tank top. Figure 8 shows a tank access riser.

Flexible expansion bellows and spray chambers were used to complete the tank confinement barriers between the access risers and pump support trusses. The expansion bellows do not structurally tie the risers to the support trusses, which enables the trusses to move freely without imparting loads to the risers and tank vault. 
The location for the additional risers was determined from the results of the reduced-scale modeling. The sludge mobilization pumps are installed in the M-1, M-2, M-3, M-5, and M-6 access risers. One of the risers contains a wash solution removal pump. The others contain shield plugs or in-tank instrumentation.

\subsubsection{Additional Confinement Barriers}

The SMWS modifications maintain confinement by way of a system of barriers and sealed connections between Tank 8D-2 and the pump support trusses. The new access risers, bellows, and spray chambers represent additional confinement barriers for the SMWS.

The confinement barriers had to be capable of withstanding design-basis accidents and still meet DOE release criteria. Analyses were performed to assess the integrity of SMWS confinement barriers under various designbasis conditions (man-made as well as natural phenomena) (Gates, 1991). The confinement barriers will survive extreme environmental loading (e.g., design-basis earthquake and tornado events) without structural failure and release of HLW into the environment because there is sufficient reserve capacity inherent in the original construction of the tank structure as well as in the design of the new components. 


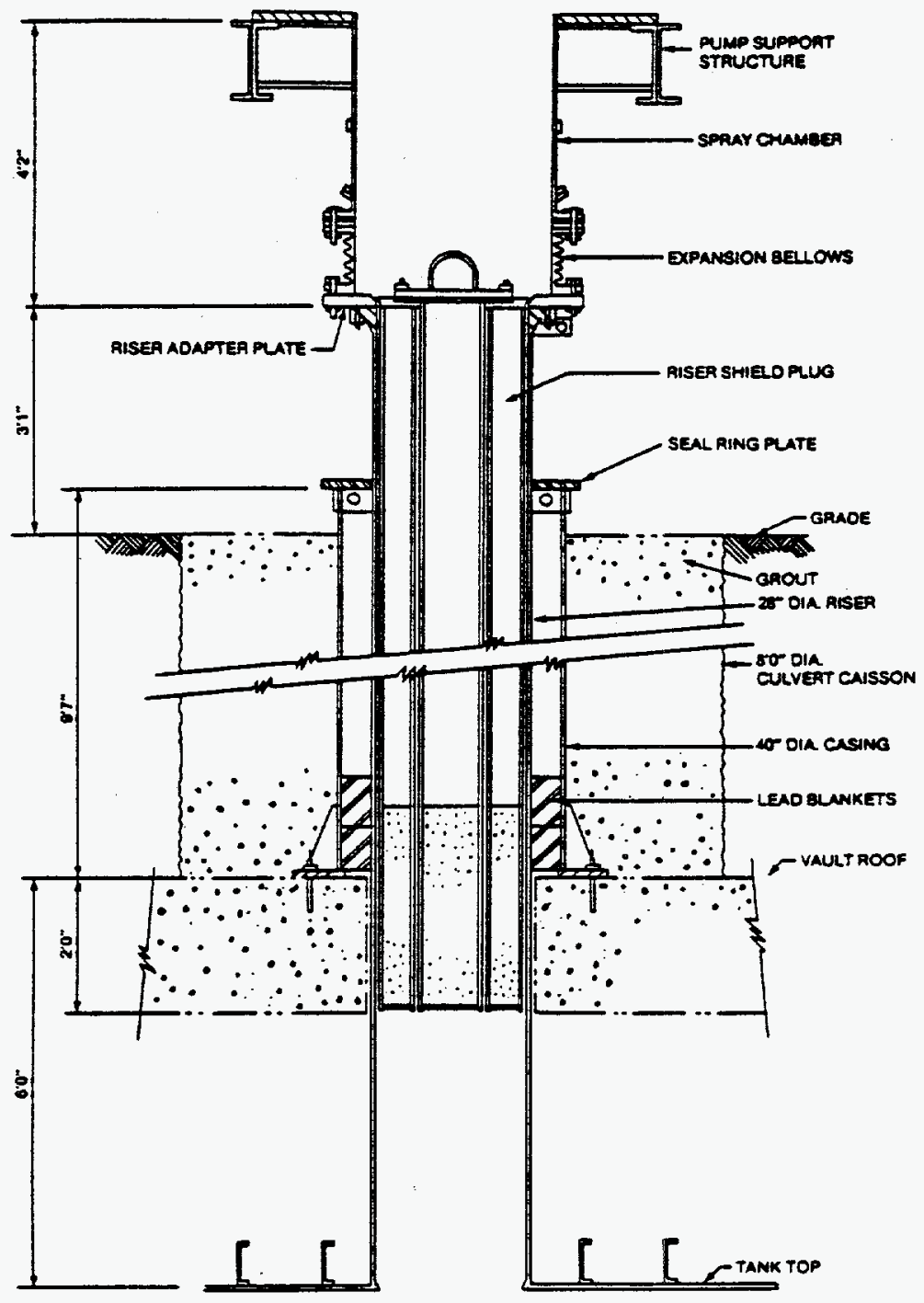

Figure 8. Tank 8D-2 Sludge Mobilization Pump Access Riser 


\subsection{EQUIPMENT PROCUREMENT}

All equipment and instrumentation for the SMWS were selected and purchased in compliance with the WVDP Quality Assurance Program, which is based on ASME NQA-1. Detailed equipment specifications were prepared by WVNS and issued for competitive bidding. The major components procured were the mobilization pumps themselves. Peabody Floway of Fresno, California, was awarded the contract to fabricate, test, and deliver the mobilization pumps. The 150-hp pump controllers also were procured through competitive bidding. Robicon of Pittsburgh, Pennsylvania, was awarded the contract to fabricate and test the pump controllers. Each of these components was extensively tested at the manufacturer to ensure that it met the equipment specifications. The pump support trusses were designed by EBASCO Services, Inc. - the resident Architect Engineer for the WVDP (EBASCO, 1985). The trusses were fabricated and installed with the other support equipment by a subcontractor. The access risers, spray chambers, and expansion bellows were purchased separately through competitive bidding and supplied to the subcontractor for installation. 


\subsection{EQUIPMENT INSTALLATION}

Installation of the SMWS components was performed by WVNS and outside subcontractors. The components installed by outside subcontractors include the pump support trusses, spray chambers and expansion bellows, electrical power and pump controls, utility water system, and pump enclosures and services. The new access risers, mobilization pumps, buoyancy probe, and density indicators were all installed by WVNS. As a rule, any equipment installation involving Tank 8D-2 access was performed by trained WVNS personnel. Because the equipment resides over a HLW storage tank containing roughly 35 million curies of activity, component design had to incorporate installation techniques that resulted in personnel receiving radiation doses as low as reasonably achievable (ALARA).

\subsection{Access Risers}

Equipment installation began with the installation of new access risers in Tank 8D-2. These access openings were the most difficult components to install because they had to be installed remotely. The access risers were used as the reference point for the installation of all other equipment since everything was placed off the riser's center line. Once the risers were installed, shield plugs were inserted into them; this permitted the use of conventional construction methods for installing the remaining components.

Installing each access riser involved five discrete steps: excavating soil to expose a portion of the concrete tank roof; removing a core from the vault roof; removing roof support beams; welding the riser to the top of the tank; and cutting the tank top through the riser.

The first step of the riser installation involved excavating soil to expose a portion of the concrete tank roof. The location of the dig was determined during scale-model testing (Schiffhauer, 1987). Once the roof was exposed, a construction caisson was installed and a 10.2-cm (4-inch) diameter pilot hole was drilled in the vault roof. The center line of the pilot hole was used to designate the center line of the access riser casing. The riser casings were fabricated during the excavation and caisson installation. Each casing was installed and stabilized after the pilot hole was drilled.

After the casing was stabilized, a concrete core was removed from the vault roof so that the tank top could be accessed. A 76.2-cm (30-inch) diameter hole was cut through the 61.0-cm (24-inch) thick concrete vault roof. This hole provided adequate clearance for the new riser. Coring was accomplished with traditional hydraulicpowered concrete coring equipment that was modified for remote applications. A coring barrel with a core retaining device was used to prevent the vault core from falling onto the tank roof. The core retaining device clutched the core through the pilot hole.

Carbon-steel beams spaced $47.5 \mathrm{~cm}$ (18 inches) apart and welded in place stabilize the tank roof. Before the riser casing could be welded to the tank, sections of the beams had to be removed. To ensure that the top of the tank was not breached, the upright sections of the beams were cut away with an oxyacetylene torch and the remainder was removed with a grinder. The rafter cutting and all subsequent steps were remotely performed from an equipment control trailer equipped with video-camera monitors, tape recorders, and specially designed control panels.

A modified commercial cutting unit was used to cut the beams. The cutter was modified so that its torch could cut in two planes. A grinding turntable was used to grind the top of the tank. The turntable was outfitted with electromagnets to hold itself in place. The grinder pivoted $35.6 \mathrm{~cm}$ (14 inches) radially about the turntable center line until a uniform circle of bright metal was visible. A boom crane was used to lower the turntable down through the riser to the tank roof. A video camera mounted on the turntable was used to monitor the grinder. 
Once the grinding was complete, the new riser was lowered onto the tank roof using a mobile crane. The grinding turntable was converted into a Metal Inert Gas (MIG) welding turntable by changing its tools. The riser-to-roof joint was visually inspected for cleanliness and fitted before welding commenced. The internal fillet weld was visually inspected with the video camera mounted on the turntable. The integrity of the weld was pressure tested with $138 \mathrm{kPa}(20 \mathrm{psi})$ of air for 30 minutes. A shielded test fixture was used to perform the tests.

A vertical preload of $35.6 \mathrm{kN}(8,000 \mathrm{lbs})$ was applied to the riser through the shielded test fixture until some load transfer devices were welded in place. The test fixture provided shielding from the HLW so that the upper riser could be manually welded. The main load transfer member was welded to the riser while maintaining the preload, which diverted the load from the tank top to the concrete vault roof when the preload was released.

The final operation in the installation was cutting the tank top through the riser to provide direct access to the tank interior. A second turntable equipped with an oxyacetylene torch was used to cut through the tank roof. The turntable was outfitted with electromagnets both to hold the turntable in place during the cutting and to retrieve the roof cutout.

Since radioactive contamination was now a possibility, the operation was performed inside a containment tent. Tank ventilation was increased to provide a $0.76 \mathrm{~m} / \mathrm{sec}$. (150 fpm) flow of air across the tank top for contamination control. A detailed discussion of the safety and environmental aspects of the access riser installation are provided in Brown (1986). The last step of the access riser installation was installing a shield plug in the riser.

\subsection{Support Trusses}

The mobilization pump support trusses were the next major components installed. Spread footer and pile foundations were installed at the same time as the access risers since these activities were independent of each other. The center line location of each access riser was as-built for locating the exact position of the pump mounting framework along the truss assembly. These dimensions were critical to the mounting of the trusses and tie-in fit from the truss mounting framework to the access riser. The installation of the trusses was performed by outside subcontractors experienced in this type of installation. The trusses were delivered to the site in three sections. A 300-ton tractor crane was used to unload the truss sections for field assembly. The crane then was used to place the assembled trusses on the sets of support columns.

\subsection{Spray Chambers and Expansion Bellows}

The spray chambers and expansion bellows were installed next. The expansion bellows attach to the riser flange. The spray chamber is attached to the truss mounting framework and extends down through the truss and over the riser flange. Ideally, the expansion bellows and bottom spray chamber flange should match up; however, measurement inaccuracies of as-built dimensions and the stack-up of construction tolerances made this difficult to achieve. To eliminate the problem of a mismatch, the riser center lines and truss framework were measured. To compensate for the mismatch between the access risers and the enormous steel trusses, each spray chamber opening, which corresponds to the riser opening, was adjusted off-center from its square mounting plate. The flexibility of the expansion bellows also enabled an unrestricted fit-up.

The installation of the spray chambers and expansion bellows was performed by the subcontractor who was contracted to install the pump electrical and pump seal water components. These components were installed as late in the installation program as possible so that the new access openings could be utilized for in-tank sampling and waste characterization studies. 


\subsection{Mobillzation Pump Services}

After the access risers, support trusses, and riser-to-truss connections were complete, the mobilization pump support services were installed. The service equipment consisted of the electrical conduit and cable, utility water piping and valves, system instrumentation, and pump weather enclosure and heater. All the electrical conduits, junction boxes, pull boxes, and motor disconnects were mounted on the support trusses. The pump controllers were wired to the motor disconnect switches by subcontractors. The pump seal water components and utility water system were also installed by outside subcontractors. The utility water system runs from the existing Tank Farm utilities to a utility instrument board in each pump weather enclosure.

\subsection{Sludge Mobillzation Pumps}

Installation of the sludge mobilization pumps was performed in two major stages. The first stage involved the installation of pump components, including the pump rotating assembly and split shims. Installation of these components did not require removal of the shield plug. The second stage involved removing the shield plug from the tank riser, installing the pump through the riser with its split support spacers attached to the top column flange, and mounting the vertical motor on the pump motor stand. The installation of these components was performed in accordance with WVDP-approved operating procedures, which require independent verification of critical procedure steps.

No special tools were required to install the pumps. The equipment required to install the pumps included, but were not limited to, the following: mobile crane with two lines, flat bed trailer, pump lifting bail, miscellaneous slings and shackles, and two forklifts.

DOE Hoisting and Rigging Manual guidelines were followed for the pump lift. Based on the guidelines, this lift was considered a High Consequence Lift and, therefore, required stringent rigging equipment load testing and mock-up training lifts. These activities were performed in accordance with approved procedures by personnel qualified to perform the actual pump installation.

Several measures were taken for contamination control. To optimize equipment protection from stress corrosion cracking caused by chlorides in contact with the stainless steel, a very stringent procedure for handling the pump was enforced. The chloride content of materials that will be in permanent contact with the stainless steel must have no more than $200 \mathrm{ppm}$-free chloride. Similarly, the pump enclosure was lined with yellow herculite for contamination control. This lining covered all exposed parts of the rotating assembly, split shims, utility board, and other miscellaneous equipment previously installed inside the enclosure. The enclosure roof was removed to enable the pump to be lowered through the tent and the access riser into the tank.

The pump and motor was transported on a flatbed truck from the hardstand to the staging point at the Tank Farm. The split support spacers were attached to the pump at the hardstand.

Prior to raising the shield plug out of the riser, the tank was ventilated using the PVS. As the shield plug was removed from the riser, a Radiation and Safety Specialist monitored the area for radiation levels and ensured that control procedures were used to minimize operator exposure over the open riser. Dose rates as high as one rad/hr are normal over the top of the open riser; however, the installation procedure did not require personnel to be over the riser at any time.

The pumps were designed to permit lifting from one end; however, when the pump was lifted from a horizontal to a vertical position, a crane with two lines was used to lift the motor stand end using a special lifting bail attached to the load line. The volute end was held off the ground by a nylon basket sling attached to the whip line to 
prevent damage to the basket strainer as the pump was brought to a vertical position. All sharp edges on the pump column were taped and/or covered where the sling was attached. This prevented the pump column guides from cutting the nylon sling when the pump was raised in the vertical position.

Once in the vertical position, the basket sling was removed and the pump was suspended over the top of the enclosure. Because of load restrictions on the tank vault roof, as well as the height of the trusses, the pump had to be lifted approximately $27.4 \mathrm{~m}(90 \mathrm{f}$.) from grade to the top of the bail.

As the pump was lowered through the riser and into the tank, the WVDP had to ensure that the pump did not catch on the split shims, rotating assembly, or tank top. The access opening in the tank roof is $67: 3 \mathrm{~cm}(26-1 / 2$ inches) in diameter. The diameter of the pump volute is $57.2 \mathrm{~cm}$ (22-1/2 inches). Two-way radios were used to maintain communication between the personnel in the enclosure and the crane operator. If the pump caught on anything, the crane was stopped and the load was readjusted.

When the pump was approximately half way through the riser, but not in the tank liquid layer, the pump column was filled with utility water to a level greater than the height of the liquid in the tank. This provided a positive liquid head on the pump lower mechanical seal and prevented any backflow of liquid into the column.

When the split support spacers were within 12.7 to $25.4 \mathrm{~cm}$ ( 5 to 10 inches) of the split shims; lowering was stopped and the alignment was adjusted between the split shims and the split support spacers. The pump was rotated as it was suspended from the crane in order to line it up with the bolt holes of the two flanges. The pump was lowered within $2.54 \mathrm{~cm}$ ( 1 inch) of the flange. The bolts between the split support plates and the split shims were installed and tightened by hand. These bolts were then used as guide pins for the placement of the pump on the mating flange of the split shims. Once the bolts were installed, the area was surveyed and smeared to ensure that it was not contaminated and that the pump lifting bail was disconnected and removed from the enclosure.

The pump half coupling, pump key, and the adjusting nut were installed on the pump head shaft. The motor then was installed on top of the pump using the crane. The driver key, motor driver half coupling, and split thrust rings were then installed to the motor coupling. The two halves of the coupling remained free and uncoupled until equipment check out was completed.

The utility water quick-coupling halves were pieced together to complete the permanent pump fill-line connection with the utility board and the column was filled with utility water. The installation was completed by cleaning the enclosure area and completing the final electrical power connections to the pump motor and rotating motor. 


\subsection{CHECK OUT}

During SMWS check out, the WVDP verified that the installation of the system components was accomplished in accordance with the system design drawings, installation specifications, and work procedures. The check out also consisted of a pre-operational program to verify that the SMWS would operate as intended and that it met equipment design objectives. The test program consisted of three check outs: factory, field, and start up. The Caustic Addition System, mobilization pumps, access risers, motor controllers, instrumentation, and utilities were all checked and verified. The check out culminated in a formal readiness review plan that was approved by DOE before the SMWS was operated.

\subsection{Caustic Addition System}

Equipment check out for the Caustic Addition System consisted of testing all the transfer lines from the tank truck load-out station to Tank 8D-2 for fluid flow and hydrostatic pressure. Individual components as well as completed assemblies were tested by the fabricator for hydrostatic pressure. Instruments in the Truck Unload Cart were tested and calibrated. A caustic spill was simulated to verify Emergency Response and Hazardous Materials Team training prior to obtaining Operational Readiness approval for performing a caustic transfer.

\subsection{Sludge Mobilization Pumps}

The manufacturer of the mobilization pumps performed acceptance tests in their factory to verify that the assembly and operation of the pumps met the equipment specifications. They performed a six-hour performance run to verify pump capacity, seal-leak rate, power consumption, and vibration levels. Lifting lugs and fixtures were load tested. ASME NQA-1 guidelines were followed to check and independently verify that nuts and bolts were tight, pump suction and discharge were clear, seals were installed properly, shaft was free to rotate, and all pre-installation requirements were met before the pump was installed. Upper mechanical settings were checked to ensure proper installation.

Field tests were performed after the installation of the mobilization pumps and their motors. Continuity, megger, and phase tests were performed to verify that the pump motors were wired properly. After installation, the motors were bump tested to confirm that they were rotating properly prior to coupling the pumps.

\subsection{Access Risers}

Access riser equipment development, fabrication, and installation was performed by Rockwell Hanford Operations (RHO). The remote risers were factory tested in Hanford, Washington, by RHO and field tested at the WVDP. Tank 8D-1 was used for the field tests. The first riser was installed by RHO personnel. The second riser was installed by WVDP personnel with RHO supervision. Three additional risers were installed on Tank 8D-1 by the WVDP to train operators and to verify equipment specifications and work procedures.

\subsection{Motor Controllers}

A series of factory tests were performed to verify that the controllers met the procurement specifications. During field testing, the motor controllers were tested, based on approved work procedures, to ensure the presence of proper input and output power. Control circuitry was also tested, based on a recommendation from the manufacturer, to verify that it was properly functioning. Once the pump motor was installed and the electricity 
connected, the controllers were run through a check-out test with the motor uncoupled from the pump. The motors and motor controllers were also fine-tuned with critical operating frequencies locked out.

\subsection{Instruments}

The assembly and operation of the pump utility system was tested by the WVDP through a Work Procedure Test Plan. During field testing, the instrument wiring was spot-checked for proper installation and continuity. Field testing also involved instrument-loop checks. These tests were performed to verify that the instrument loops were connected and that switches functioned properly. The loops were then operated to check performance and to test for response to the initiating event - low seal water pressure and high seal water flow. Finally, all instruments were calibrated and labelled based on WVDP-approved procedures. For example, the buoyancy probe was calibrated for density and length measurements. Functional checks also were performed on a mock-up to ensure that the buoyancy probe components worked as required.

\subsection{Utilities}

All mechanical and electrical components, including piping and wiring, were checked and tested in the field to ensure proper installation and operation.

\subsubsection{Electrical}

Electrical outlets were tested to ensure proper installation and the presence of $\mathrm{AC}$ power. Electrical power and wires were spot-checked for continuity. Tests were also performed to verify that no breaks existed in the electrical wiring. Power cables were meggered and each connection inspected.

\subsubsection{Utility Water}

The utility water piping system hydrostatic pressure was tested to ensure that fittings and valves were tight. Seal water pressure and flow were checked at the pump. The low-pressure and high-flow switches for the pump seal water system were checked to verify that equipment interlock functions were operational. Valve orientation was also checked and verified. 


\subsection{PROBLEMS ENCOUNTERED AND LESSONS LEARNED}

The WVDP encountered some problems during the installation and check out of the SMWS. Removing the original access riser shield plug, positioning the mobilization pumps, stabilizing the motor controllers, and preventing mechanical seal leakage all required innovative solutions.

\subsection{Removing the Old Shield Plug}

The shield plug in the only original access opening on Tank 8D-2 could not be removed when attempting to install support equipment. The plug had not been removed from the riser since it was originally installed. Equipment was designed to simultaneously rotate the plug back and forth with hydraulic cylinders and lift it. A vibrator was also attached to the plug to help loosen any rust or scale restricting the plug removal. Similarly, a steam line was attached to the sleeve surrounding the outer riser. The steam was used to expand the riser and try to create a larger gap between the plug and the riser. The rotating and lifting technique was a success at freeing and removing the old shield plug.

\subsection{Positioning the Sludge Mobilization Pumps}

The integrity of the existing in-tank equipment to withstand the impact of the liquid jets from the mobilization pumps had to be analytically verified as a requirement of a Safety Analysis Report. To satisfy the requirement, two of the five pumps were initially operated at a maximum of $60 \%$ speed and not allowed to rotate until the pumps were lowered into the bottom gridwork of the tank. This condition was imposed because, when these two pumps were rotated in a particular alignment, the liquid jets from the pumps struck an existing heat exchanger suspended in the tank. Repositioning the pump nozzles solved the problem. Before starting these pumps, the pump rotating assembly was used to position the pump discharge nozzles 90 degrees away from the heat exchanger. Once the pumps were lowered into the bottom gridwork where the liquid jets could no longer reach the exchanger, the pumps were allowed to rotate and run at full speed.

\subsection{Stabllizing the Motor Controllers}

The five mobilization pump variable frequency motor controller drives required stability tuning (adjustments) under load; however, the controllers could not be stabilized above $95 \%$ motor speed $(1,700 \mathrm{rpm})$. The controllers tripped out above $1,700 \mathrm{rpm}$. Through the controller diagnostics display it was determined that the controller output voltage was too low. The controller manufacturer recommended that the controller capacitors be adjusted. A commutation capacitor from each capacitor was removed to raise the output voltage. The WVDP was running a 150-hp motor with a 200-hp controller. Adjusting the controller capacitors solved the problem. The adjustments made the controller compatible with the motor - the three controllers became operational at 1,800 rpm.

Other minor problems occurred after the pumps were operating at full speed. One controller was tripping in the early evening. It was determined that the low-voltage trip setting for this controller was 460 volts. Normally, it was set at 400 to 430 volts. The tripping occurred in November around 5:00 to 5:30 pm - when lights are turned on because it gets dark earlier in the evening. The problem was solved by setting the low-voltage trip setting for the controller to 425 volts. 
The utility system high-flow switch presented another problem. In some cases, the pump. would start but would not run above approximately $20 \%$ speed before tripping. No fault indication was given on the controller fault indicating module. Troubleshooting showed no apparent reason for the flow switch trip. All the flow switches had been set to their lowest setting during equipment check out. At this setting, these switches were very sensitive and small vibrations were tripping the switches that shut down the pump. The switches were set to the midpoint setting and the problem was resolved. Additional fine tuning of each controller resulted in smooth and stable operation for the remainder of the operational run.

\subsection{Preventing Mechanical Seal Leakage}

The problem of tank materials migrating into the pump column had been experienced in the past at both the Savannah River and West Valley sites. The problem had occurred at West Valley on a pump installed in Tank 8D-1. As a result, the pumps in Tank 8D-2 were modified to the extent possible to prevent this from occurring. The pumps were modified to contain the contamination and discharge it back to the tank. After the completion of the operational run, however, normal radiation surveys revealed contamination that ranged from 350 to 3,000 dpm around the mobilization pump upper mechanical seal, even though the pump seal water system was designed to deal with this problem. The results of the survey indicated that the pump modifications were unsuccessful. The pumps, therefore, will be monitored closely during the next operation run to determine if the problem worsens. 


\subsection{CONCLUSION}

The SMWS test program verified that the system operates as intended and meets the equipment design objectives. Check outs, such as installing the five risers in Tank 8D-1 and practicing remote operations, ensured that personnel exposure was kept ALARA during Tank 8D-2 installations.

Factory check-out testing verified that the components met procurement and equipment specification requirements prior to the transfer of ownership. In the case of the mobilization pumps, the factory testing of the fully assembled units eliminated the requirement for operational testing at the site prior to installation and provided some advanced insight into equipment interfaces at the site.

During field check out, each component was checked for proper installation and identification, freedom of operation, and functional operation of the component with its associated instrumentation and interlocks. During the check-out phase, testing confirmed that most of the components, as originally installed, were properly labelled and functioned properly. Most of the problems encountered were minor and were resolved as they were discovered.

The five mobilization pumps effectively resuspended the settled sludge at the bottom of Tank 8D-2. Shim removal was completed in less runs than originally planned. The original $50.8 \mathrm{~cm}$ (20 inches) of settled sludge was resuspended to the extent that the pumps could be placed in their final position within three separate operational runs. The average sludge height was $50.8 \mathrm{~cm}$ ( 20 inches) at all access risers. The original sludge depth varied from 40.6 to $63.5 \mathrm{~cm}$ (16 to 25 inches). In the first run, the pumps were lowered from 15.2 to 22.9 $\mathrm{cm}$ ( 6 to 9 inches). After the second run, they were lowered another 22.9 to $30.5 \mathrm{~cm}$ (9 to 12 inches). After the third run, the buoyancy probe was lowered and reached the tank floor for the first time. Initial reading prior to pump start up was $58.4 \mathrm{~cm}$ (23 inches); therefore, following the third run, all the pumps, with the exception of one - the pump with the most shims at the start - were placed in their final position. Lowering the last pump was accomplished after the fourth run.

Once all five pumps were lowered into their final position, the pumps were run continuously for 72 hours to dissolve the salt crystals and wash the sludge of the interstitial salts. Operating the five pumps for over 72 hours only raised the temperature of the tank $3^{\circ} \mathrm{F}$ - from 135 to $138^{\circ} \mathrm{F}\left(57\right.$ to $\left.59^{\circ} \mathrm{C}\right)$, which is negligible. After this run, samples of the liquid were taken and the salt concentrations were analyzed. Buoyancy probe measurements confirmed that the sludge was resuspended off the floor and laboratory analyses confirmed that the sludge was washed as anticipated. The first sludge wash in Tank 8D-2 was complete. 


\subsection{REFERENCES}

Baker, 1989

Bray, 1990

Brown, 1986

Chapman, 1988

EBASCO, 1985

EBASCO, 1986

Eisenstatt, 1986

Gates, 1991

Jackson, 1988

Jezek, 1988

Ploetz, 1988

Rykken, 1986

Schiffhauer, 1985

Schiffhauer, 1987

Skillern, 1986
Baker, M. N., W. E. Mateer, G. H. Metzler, S. R. Reeves, and D. J. Rickettson. "Design and Construction of the Low-level Liquid Waste Treatment System," April 28, 1989, DOE/NE/44139-56 (89009023).

Bray, L. A., Frank T. Hara, and Thomas F. Kazmierczak. "Evaluation and Selection of a Process to Remove Plutonium from West Valley High-level Waste Sludge Wash Water," December 1990, Draft C.

Brown, S. H. "Safety Analysis Report for Remote Riser Installation and Penetration of Tank 8D-2," May 1986, Memo from S. H. Brown to R. R. Borisch (HE:86:0097).

Chapman, C. C., and W. P. Drosjack. "Vitrification Process Equipment Design for the WVDP," March 12, 1988, DOE/NE/44139-42 (DE89009021).

EBASCO Services, Inc. "Pump Support Structure Design Conditions," February 1985, WVDP-EBAR-735 and 735A.

EBASCO Services, Inc. "STS 8D-1 Tank Vault Top Slab Design Evaluation," 1986, WVDP/W50.

Eisenstatt, L. R. "Description of the WVDP Reference HLW Form and Canister," July 28, 1986, WVDP-56, Rev. 0.

Dames and Moore. "8D-2 Sludge Mobilization System Confinement Barrier Integrity Review," April 30, 1991, Subcontract No. 19-CWV-21511, Task 10.

Jackson, J. P., and R. F. Gessner. "Remote Installation of Risers on Underground Nuclear Waste Storage Tanks," March 1988, DOE/NE/44139-45 (DE88010531).

G. R. Jezek. "Low-level Waste Cement Solidification Design, Installation, and Start Up," August 31, 1988, DOE/NE/44139-50 (DE89009015).

Ploetz, D. K., and I. M. Leonard. "Supernatant Treatment System Design Through Testing," December 1988, DOE/NE/44139-47 (DE89009020).

Rykken, L. L. "High-level Waste Characterization at West Valley," June 1986, DOE/NE/44139-14 (TE87005887).

Schiffhauer, M. A., D. E. Carl, and L. L. Rykken. "Design of a High-level Waste Pretreatment Process for the Purpose of Vitrification," 1985.

Schiffhauer, M. A., and R. E. Inzana. "Scale Model Equipment Testing," June 1987, DOE/NE/44139-36 (DE88007138).

Skillern, C. G. "WVDP Facilities Utilization Plan for the Existing Facilities at WNYNSC," May 1986, DOE/NE/44139-12 (DE87005886). 